\title{
The Brn-3 Family of POU-Domain Factors: Primary Structure, Binding Specificity, and Expression in Subsets of Retinal Ganglion Cells and Somatosensory Neurons
}

\author{
Mengqing Xiang, ${ }^{1,2,4}$ Lijuan Zhou ${ }^{1,2,4}$ Jennifer P. Macke, ${ }^{1,2,4}$ Takashi Yoshioka, ${ }^{5}$ Stewart H. C. Hendry, ${ }^{2,5}$ Roger \\ L. Eddy, ${ }^{6}$ Thomas B. Shows, ${ }^{6}$ and Jeremy Nathans ${ }^{1,2,3,4}$ \\ 'Department of Molecular Biology and Genetics, ${ }^{2}$ Department of Neuroscience, ${ }^{3}$ Wilmer Ophthalmological Institute, \\ ${ }^{4}$ Howard Hughes Medical Institute, and ${ }^{5}$ Zanvyl Krieger Mind/Brain Institute, The Johns Hopkins University School \\ of Medicine, Baltimore, Maryland 21205, and 'Department of Human Genetics, Rosewell Park Cancer Institute, \\ Buffalo, New York 14263
}

A search for POU domain sequences expressed in the human retina has led to the identification of three closely related genes: Brn-3a, Brn-3b, and Brn-3c. The structure and expression pattern of Brn-3b was reported earlier (Xiang et al., 1993); we report here the structures and expression patterns of Brn-3a and Brn-3c. Antibodies specific for each Brn-3 protein were generated and shown to label only ganglion cells in a variety of vertebrate retinas. A complex pattern of strongly and weakly immunolabeled ganglion cells was observed in mouse, cat, and monkey retinae. In mouse and cat retinae, Brn-3a and Brn-3b proteins are found in a large fraction of ganglion cells, whereas Brn-3c is present in fewer ganglion cells. In the cat retina, anti-Brn-3a immunoreactivity was strong in the small ganglion cells $(\gamma$ cells) and weak in the remaining ganglion cells ( $\alpha$ and $\beta$ cells); anti-Brn-3b immunoreactivity was present in all ganglion cells; and anti-Brn3c immunoreactivity was confined to the small ganglion cells. Immunolabeling of macaque retinae following retrograde labeling from the lateral geniculate nucleus revealed strong anti-Brn-3a immunoreactivity in a minority of retrogradely labeled P-type ganglion cells, and weak Brn-3a immunoreactivity in all of the remaining P- and M-type ganglion cells. In the same retinae, strong anti-Brn-3b immunoreactivity was seen in nearly all P-type ganglion cells and weak immunoreactivity in nearly all M-type ganglion cells. Each of the Brn-3-specific antibodies also labeled subsets of neurons in the dorsal root and trigeminal ganglia, suggesting that primary somatosensory neurons and retinal ganglion cells share genetic regulatory hierarchies. In vitro selection of an optimal DNA binding site using the Brn-3b POU domain has revealed a consen-

Received Dec. 13, 1994; revised Feb. 8, 1995; accepted Feb. 13, 1995

We thank Dr. Clark Riley, Ms. Carol Davenport, and Ms. Janine Ptak for synthetic oligonucleotides; Dr. Keith Fry for the gift of mAb AB5; Ms. Cathy Blizzard for cat eyes; Dr. Mark Molliver for donating fixed monkey eyes; Drs. Masafumi Tanaka and Winship Herr for Oct-1 cDNA; Mr. Hao Zhou for the GST-Oct-1 POU domain protein: Dr. Y.-W. Peng for rabbit retinas and Dr. HuaShun Li for chicken retinas; Dr. Elio Raviola for advice on histologic techniques; and Drs. Robert Rodieck, Jen-Chih Hsieh, and King-wai Yau for helpful comments on the manuscript. This work was supported by the Howard Hughes Medical Institute and the National Eye Institute, NIH.

Correspondence should be addressed to Jeremy Nathans, 805 PCTB, 725 North Wolfe Street, Johns Hopkins University School of Medicine, Baltimore, MD 21205.

Copyright $(\mathcal{C} 1995$ Society for Neuroscience $0270-6474 / 95 / 154762-24 \$ 05.00 / 0$ sus $[(A / G) C T C A T T A A(T / C)]$ that is recognized by each of the Brn-3 POU domains and is distinct from binding sites previously described for other POU domain proteins.

[Key words: retina, dorsal root ganglia, retinal ganglion cells, POU-domain, retinal development]

The vertebrate retina consists of three cell layers: the outer layer contains the primary sensory cells, the rods and cones; the central layer contains a diverse group of interneurons, the bipolar, horizontal, and amacrine cells; and the inner layer contains both the output neurons, the ganglion cells, and displaced amacrine cells (Rodieck, 1973; Dowling, 1987). Most of these cell classes can be further divided into a number of types that differ in their functional and morphological properties. For example, hipolar cells differ in the polarity of their responses to glutamatergic input from the presynaptic photoreceptor cells, thereby generating either ON or OFF responses to changes in light intensity (Werblin and Dowling, 1969; Kaneko, 1970). The retina uses this diversity of cell types to produce a complex output in which the visual stimulus is analyzed with respect to its chromatic, spatial, and temporal properties.

Retinal ganglion cells can be divided into distinct classes based upon their response properties, morphologies, and central projections (DeMonasterio and Gouras, 1975; Rodieck and Brenning, 1983; Stone, 1983; Spillman and Werner, 1990; Wassle and Boycott, 1991). In amphibia, ganglion cells with a high degree of selectivity are common, project principally to the tectum, and mediate simple visually guided behaviors (Barlow, 1953; Lettvin et al., 1959). In mammals, a larger fraction of ganglion cells have simple receptive fields and project to the LGN, forming the first stage of the retino-thalamo-cortical pathway. In the cat the principal division of these cells is into $X$ and $Y$ types, the former responding linearly and the latter nonlinearly. In the primate retina, current evidence indicates that one principal division among ganglion cells that project to the LGN is into $\mathrm{P}$ and $\mathrm{M}$ types; which project, respectively, to the parvocellular and magnocellular layers of the LGN. In general terms, P-cells are characterized by relatively slow conduction velocities, insensitivity to small changes in luminance contrast, and high spatial resolution, especially near the fovea. Most P-cells appear to have a chromatically opponent organization that is built from either concentric or superimposed antagonistic inputs. By contrast, $\mathrm{M}$-cells are characterized by relatively fast 
conduction velocities, sensitivity to small changes in luminance contrast, and low spatial resolution. M-cells have achromatic center-surround receptive fields. The different characteristics of $P$ and $M$ type ganglion cells have attracted considerable interest because these cells represent the first stage at which separate and parallel streams of information can be recognized in the retino-thalamo-cortical pathway (Spillman and Werner, 1990; Merigan and Maunsell, 1993).

One approach to studying ganglion cell diversity involves identifying the genetic regulatory circuits that specify each distinctive cellular phenotype. In an initial step in this direction, we recently reported the identification of a POU domain gene, Brn-3b, that is expressed in a subset of retinal ganglion cells in a variety of vertebrates (Xiang et al., 1993). The POU domain family of transcription factors is defined by the presence of a bipartite DNA binding domain consisting of a POU-specific domain of approximately 70 amino acids and a POU-homeo domain of approximately 60 amino acids, separated by a variable linker (Herr et al., 1988; Rosenfeld, 1991). Several POU domain genes are known to be involved in the terminally differentiated phenotype of the cells in which they are expressed: Pit-1 in the growth hormone secreting cells of the anterior pituitary (Bodner et al., 1988; Ingraham et al., 1988; Li et al., 1990), Oct-2 in B-cells (Clerc et al., 1988; Scheidereit et al., 1988; Corcoran et al., 1993), and Unc-86 in a variety of sensory neurons in the nematode Caenorhabditis elegans (Chalfie et al., 1981; Finney et al., 1988). In the experiments reported here we have extended this approach to identify two more POU-domain genes, Brn-3a and $\mathrm{Brn}-3 \mathrm{c}$, that together with Brn-3h define a family of putative transcription factors, each of which is expressed in retinal ganglion cells. As described below, the Brn-3 proteins bind to a novel DNA sequence and they are expressed in a complex pattern of overlapping sets of ganglion cells. Their pattern of expression also reveals an unexpected commonality between retinal ganglion cells and primary somatosensory neurons.

\section{Materials and Methods}

Cloning and sequencing of the Brm-3a and Brn-3c genes. A POU domain DNA sequence, later identified as Brn-3a, was amplified by PCR from a human retina cDNA library in lambda gt 10 (Nathans et al., 1986) as described previously (Xiang et al., 1993). A human genomic DNA library in EMBL3 was constructed from size-fractionated Sau3A partial digest genomic DNA as described by Frischauf et al. (1983) and screened using a mixed probe consisting of the Brn-3a and the previously isolated Brn-3b (Xiang et al., 1993) POU domains. The human retina cDNA library was similarly screened. Genomic DNA clones were identified that correspond to Brn-3a, Brn-3b, and a novel POU domain, Brn-3c. Two Brn-3a cDNA clones (hs204 and hs210) were identified (Fig. 1). Following restriction mapping and Southern blot analysis of these clones, the cDNA clones and the genomic DNA regions corresponding to the Brn- $3 \mathrm{a}$ and $\mathrm{Brn}-3 \mathrm{c}$ open reading frames were subcloned into pBluescript (Stratagene) and sequenced on both strands by the chain termination method. A several hundred base G-C-rich region in the Brn-3a open reading frame was sequenced by the chemical cleavage method (Maxam and Gilbert, 1980).

Chromosome mapping. Human-mouse somatic cell hybrids derived from 18 unrelated human cell lines and 4 mouse cell lines were characterized by karyotypic analysis and mapped enzyme markers as described previously (Shows et al., 1978, 1982, 1984; Naylor et al., 1983). A $0.6 \mathrm{~kb}$ EcoRI fragment in the 3' untranslated region of the Brn-3a cDNA clone hs204 and a $0.4 \mathrm{~kb}$ SmaI-EcoRV fragment immediately $3^{\prime}$ to the Brn-3c coding region (Fig. 1) were found to hybridize specifically to the human Brn-3a and Brn-3c genes, respectively. These fragments were used to probe genomic Southern blots of HindIII digested DNA from either 29 or 30 human-mouse hybrid cell lines, respectively. The hybridizing bands were scored and compared with the scoring of human chromosomes in each hybrid.

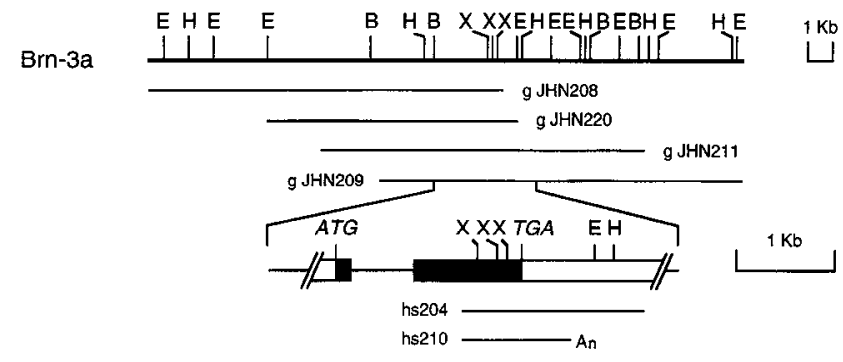

Brn-3c
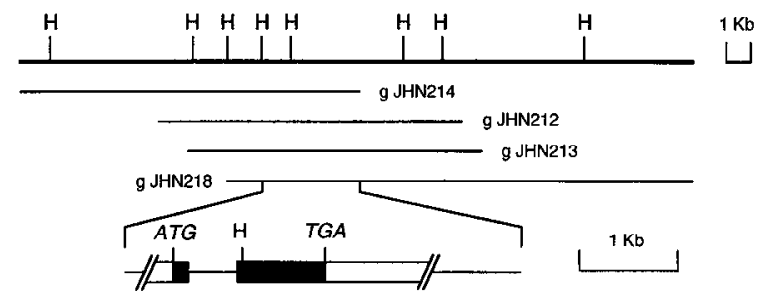

Figure 1. Brn-3a and Brn-3c gene structures. The two bold lines represent the Brn-3a and Brn-3c genomic DNA regions defined by the cloned genomic segments, which are shown underneath as overlapping lines. Enlarged at the center are the transcribed regions. The solid bars represent the protein coding regions; the open bars represent the $5^{\prime}$ and $3^{\prime}$ untranslated regions. The positions of the initiation codon $(A T G)$ and termination codon $(T G A)$ are indicated. The start sites of transcription have not been defined. Two Brn-3a cDNA clones are represented by two overlapping lines under the enlarged segment, one of which has a polyA tail and is marked $A_{n}$. Abbreviations for restriction enzymes are as follows: $B$, BamHI; $E$, EcoRI; $H$, HindIII; $X$, Xhol. HindIII was the only enzyme used to construct the Brn-3c restriction map.

Reverse transcription-PCR (RT-PCR) assay. For each $\mathrm{Brn}-3$ gene a pair of PCR primers was used that flank the intron: Brn-3a, $5^{\prime}$-CCCTGAGCACAAGTACCCGTCGCTGC- $3^{\prime}$ and 5'-CCGGCTTGAAAGGATGGCTCTTGCCC-3'; Brn-3b, 5'-CGGGGGCTCGGAGGCTATGCGGAGAGC-3' and 5'-TCCACGGCTGCCAGAGCCTCGGCGCG-3'; Brn-3c, 5'-ACCCAAATTCTCCAGTCTGCACTCTG-3' and 5'-GCGTGCCAGCAGGCTCTCATCAAAGC-3'. DNA products were generated by PCR under standard conditions using as template either first strand cDNA prepared from human retina RNA, DNA from a human retina cDNA library, or human genomic DNA. The PCR products were separated on an agarose gel, transferred to a GeneScreen Plus filter (Du Pont), and hybridized at room tempcraturc in $4 \times$ SSC $(1 \times$ SSC is 0.2 $\mathrm{M} \mathrm{NaCl}, 0.02 \mathrm{M} \mathrm{Na}$ citrate, $\mathrm{pH} 7$ ) to 24 base oligonucleotide probes, the sequences of which consist of the last 12 nucleotides of the first coding exon and the first 12 nucleotides of the second coding exon for each $\mathrm{Brn}-3$ gene. The three oligonucleotides used are as follows: Brn3a, 5'-ACGCCGCCGCTGCAGAGCAACCTC-3'; Brn-3b, 5'-CCAACCCCACCGAGCAATATATTC-3'; Brn-3c, 5'-CCCAGCCCCGCAGCAGCAGGGTAA-3'. Following hybridization, each blot was washed in $3 \times \mathrm{SSC}, 0.1 \%$ SDS at progressively increasing temperature. In a separate experiment, the smaller PCR products derived from human retina first strand cDNA were gel purified, subcloned, and sequenced.

Generation and purification of antibodies against Brn-3a and Brn3c. To produce the Brn-3a FP2' coding segment, two DNA oligonucleotides, 5'-CGATGAATTCCTACTTGGAGGATCAGCTCATCCTCATCCTCATATGCATAGTCTAGGTCATCTATCACATCCTGCA-

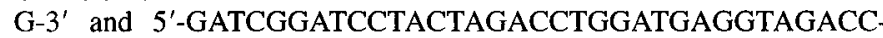
TGATGGCATGTTCATTGCAGCTGCAGCTGCAGGATGTGATAGA-3', were annealed and filled in using the Klenow fragment of DNA polymerase I. The resulting double stranded DNA fragment encodes a polypeptide corresponding to amino acids $186-224$ (Brn-3a FP2') but is less G-C-rich than the human DNA sequence due to silent third position changes. The Brn-3a FP1 and Brn-3c FP2 coding segments (Fig. 2) were generated by PCR using the cloned genomic DNA as template. Each coding segment was fused in frame to the $3^{\prime}$ end of the bacteriophage T7 gene 10 coding region in the pGEMEX expression vector (Promega; Studier et al., 1990). The resulting fusion proteins were produced in $E$. coli (strain BL21), purified to near homogeneity by pre- 


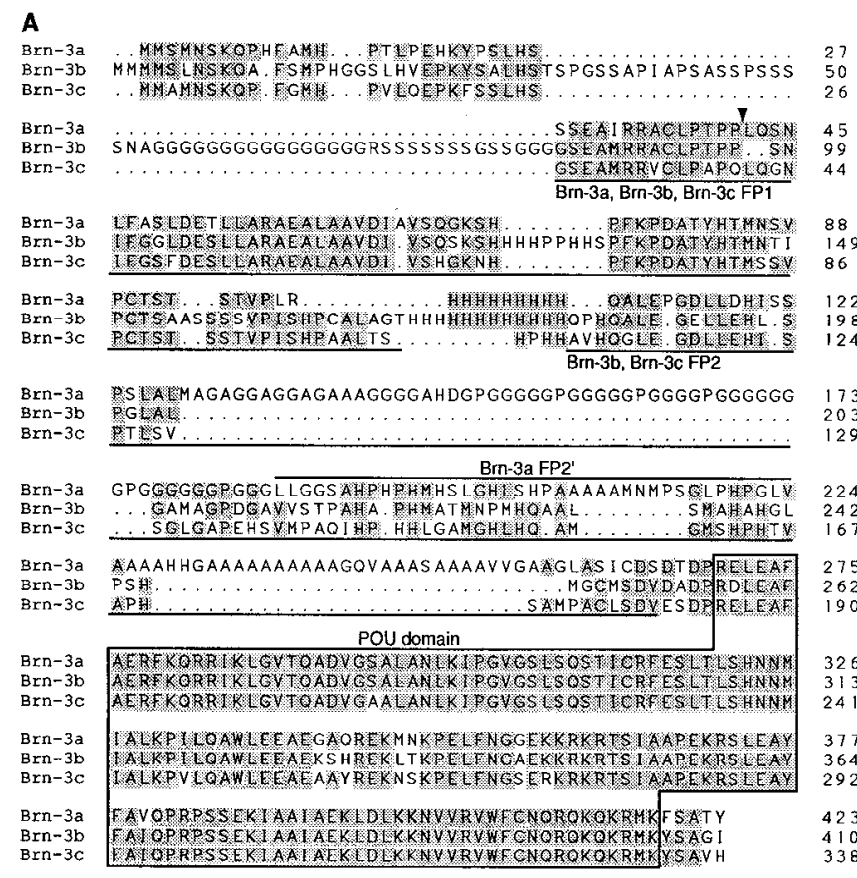

B

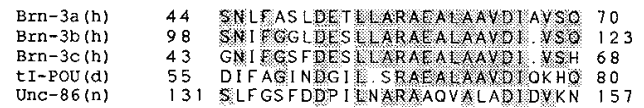

Figure 2. Brn-3a, Brn-3b, and Brn-3c protein sequences. A, Alignment of Brn-3a, Brn- $3 b$ and Brn-3c protein sequences. Amino acids that are conserved between two or more sequences are shaded. The POU domain is boxed. The arrowhead indicates the intron position for the three Brn-3 genes. The polypeptide regions used to construct fusion proteins (FP1, FP2, and $\mathrm{FP}^{\prime}$ ) are indicated by solid lines either above or below the sequences. $B$. Comparison of amino acid sequences in the upstream homology domain among the human $(h) \mathrm{Brn}-3$, the Drosophila $(d)$ tI-POU and the nematode $(n)$ Unc-86 proteins. Amino acids that are conserved among three or more sequences are shaded. The GenBank accession numbers for these sequences are, for Brn-3a, U10062 and U10063; Brn-3b, U06233; Brn-3c, U10060 and U10061.

parative SDS-polyacrylamide gel electrophoresis, and used for immunizing rabbits. For affinity purification of antibodies, fusion proteins between the $E$. coli maltose binding protein (MBP) and each of the Brn3-derived polypeptides used for immunization were produced in $E$. coli using the pMAL-cR1 expression vector (New England Biolabs) and affinity-purified on an amylose resin to apparent homogeneity as determined by SDS-polyacrylamide gel electrophoresis. Affinity purification was carried out with either $500 \mu \mathrm{g}$ of MBP fusion protein coupled to an AminoLink column (Pierce) or $250 \mu \mathrm{g}$ electroblotted onto a nitrocellulose filter using elution in $0.1 \mathrm{M}$ glycine $\mathrm{pH} 2.8$ (Harlow and Lane, 1988). In general, the nitrocellulose method yielded antibodies of higher specificity.

Western blotting. MBP fusion proteins with Brn-3a FP2', Brn-3b FP2 (Xiang et al., 1993), and Brn-3c FP2 (1.5 $\mu \mathrm{g}$ each) were resolved on a $10 \%$ SDS-polyacrylamide gel, transferred to nitrocellulose and immunoreacted sequentially with affinity-purificd anti-Brn-3a FP2', anti-Brn$3 \mathrm{~b}$ FP2, and anti-Brn-3c FP2. Signals were visualized by the enhanced chemiluminescence (ECL, Amersham) detection system according to the inanufacturer's protocol. For sequential reactions, the blot was dried at room temperature for several days to inactivate any remaining peroxidase and washed in water for $20 \mathrm{~min}$ to remove the ECL reagents. The anti-Brn-3a FP2' antibody reacts poorly using standard Western blot procedures. To increase the signal from this antibody, $10 \mu \mathrm{g}$ of each MBP fusion protein was resolved by SDS-PAGE and transferred to a nitrocellulose filter as described above. Following a $10 \mathrm{~min}$ rinse in TBS [10 mM Tris ( $\mathrm{pH} \mathrm{8.0),150} \mathrm{mM} \mathrm{NaCl],} \mathrm{the} \mathrm{immobilized} \mathrm{proteins}$ were denatured by two incubations of the blot in a denaturation solution $\left(6 \mathrm{M}\right.$ guanidine hydrochloride in TBS) for $5 \mathrm{~min}$ at $4^{\circ} \mathrm{C}$. The proteins were then gradually renatured at $4^{\circ} \mathrm{C}$ using a series of five serial twofold dilutions of denaturation solution in TBS (Vinson et al., 1988). After two additional rinses in TBS at room temperature, the blot was immunoreacted with the anti-Brn-3a FP2' antibody.

Immunohistochemistry. To prepare cryosections from mouse tissues, adult animals were anesthetized and perfused by cardiac puncture with PBS followed by $4 \%$ paraformaldehyde in PBS. Following enucleation of the eyes, the cornea and lens were removed, and the eye cups, whole brain, and various other tissues postfixed overnight in $4 \%$ paraformaldehyde in PBS at $4^{\circ} \mathrm{C}$, cryoprotected overnight in $30 \%$ sucrose in PRS at $4^{\circ} \mathrm{C}$, embedded in OCT compound, frozen in liquid nitrogen, and stored at $-80^{\circ} \mathrm{C}$. Sections $(10-25 \mu \mathrm{m}$ thick) were cut on a Microm cryostat at $-20^{\circ} \mathrm{C}$ and mounted on gelatin coated slides.

To prepare cryosections from the macaque retina, eyes were enucleated from an animal that had been anesthetized and perfused with $4 \%$ paraformaldehyde in PBS. The cornea, lens, and vitreous were removed and the eye cups postfixed in $4 \%$ paraformaldehyde in PBS and cryoprotected in $8 \%$ sucrose in PBS. A strip of retina $(\sim 5 \mathrm{~mm}$ in width) which included the fovea was cut from the entire horizontal meridian and divided into 14 segments of approximately equal size $(-2.3 \times 5$ $\mathrm{mm}$ ). Each segment was embedded in OCT compound, frozen in liquid nitrogen and cut into either $5 \mu \mathrm{m}$ sections (for the central segments) or $10 \mu \mathrm{m}$ sections (for the peripheral segments). Rabbit and chicken retina sections were prepared in a similar manner without division into segments of defined location.

Immunostaining of cryosections of retina, brain, and peripheral tissucs was performed using the ABC system (Vector Laboratories) according to the manufacturer's instructions except that cryosections were postfixed in $100 \%$ cold methanol for $3 \mathrm{~min}$ prior to incubation with primary antibodies overnight at $4^{\circ} \mathrm{C}$. The horse radish peroxidase (HRP) color stain was developed using the VIP substrate kit (Vector Laboratories). Procedures for double staining of cryosections with DAPI or with monoclonal antibody AB5 (Fry et al., 1985) were as described in Xiang et al. (1993). In the analysis of immunostaining in the brain, neuroanatomical assignments were made with reference to Sidman et al. (1971) and Paxinos and Watson (1986). For quantitation of immunostained nuclei in sections of mouse and monkey retinas, sections that were double stained with DAPI and the indicated antibody or mixture of antibodies were examined with a Zeiss Axiophot under combined UV and visible light, and the total number of nuclei (DAPI stained) as well as the number of immunostained nuclei (HRP stained) were counted. For each data point, greater than 200 nuclei were counted.

The procedure for immunostaining of flat-mount retinae was modified from fry and Lam (1986). Macaque or cat eye-cups prepared from either unperfused or $4 \%$ paraformaldehyde perfused animals, were fixed overnight in $4 \%$ paraformaldehyde in PBS at $4^{\circ} \mathrm{C}$ and then cryoprotected overnight in $30 \%$ sucrose in PBS at $4^{\circ} \mathrm{C}$. The retinae were peeled off, and then frozen and thawed in liquid nitrogen seven times while immersed in $30 \%$ sucrose to aid penetration of the antibodies. After the retinae were rinsed three times in PBS for $5 \mathrm{~min}$ each, they were blocked in 5\% normal goat serum in PBS for $6 \mathrm{hr}$ at room temperature, and incubated for $10 \mathrm{~d}$ at $4{ }^{\circ} \mathrm{C}$ in the primary antibody diluted in $5 \%$ normal goat serum in PBS with $0.3 \%$ Triton X-100 and $0.05 \%$ sodium azide. The retinae were then rinsed three times in PBS for $2.5 \mathrm{hr}$ each at room temperature prior to incubating for $2 \mathrm{~d}$ at $4^{\circ} \mathrm{C}$ in biotinylated secondary antibodies (1:200; Vector Laboratories) diluted in PBS with $0.3 \%$ Triton X-100. Following incubation in secondary antibodies, the retinae were again rinsed in PBS three times for $2.5 \mathrm{hr}$ each at room temperature, and incubated for $2 \mathrm{~d}$ at $4^{\circ} \mathrm{C}$ in the avidin-biotin-peroxidase complex (A+B, 1:100; Vector Laboratories) diluted in PBS with $0.3 \%$ Triton X-100. After rinsing the retinae in PBS three times for 2 $\mathrm{hr}$ each, the staining was visualized using the diaminobenzidine (brown) or VIP (purple) substrate kits (Vector Laboratories). The retinae were then flattened on microslides and mounted with Aqua-poly/mount (Polysciences). For double immunostaining of flat-mount retinae, the primary antibodies consisted of the desired Brn-3 antibodies together with monoclonal antibody SMI-32 (Sternberger Monoclonals; Nixon et al., 1989) or AB5 (Fry et al., 1985), and the secondary antibodies were FI'IC-conjugated donkey anti-mouse $\lg G$ (1:50; Jackson Immunoresearch Laboratories) and the biotinylated anti-rabbit antibody described above. To measure cell body sizes, color slides were taken at $400 \times$ magnification on a Zeiss Axiophot microscope. The average of the lengths of the long and short axes of the cell body was taken as its soma diameter.

Retrograde labeling from the lateral geniculate nucleus ( $L G N)$. In- 


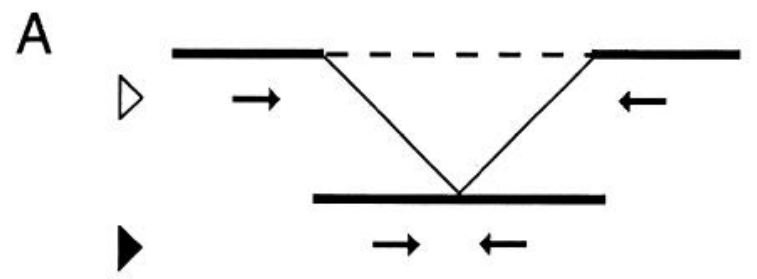

B

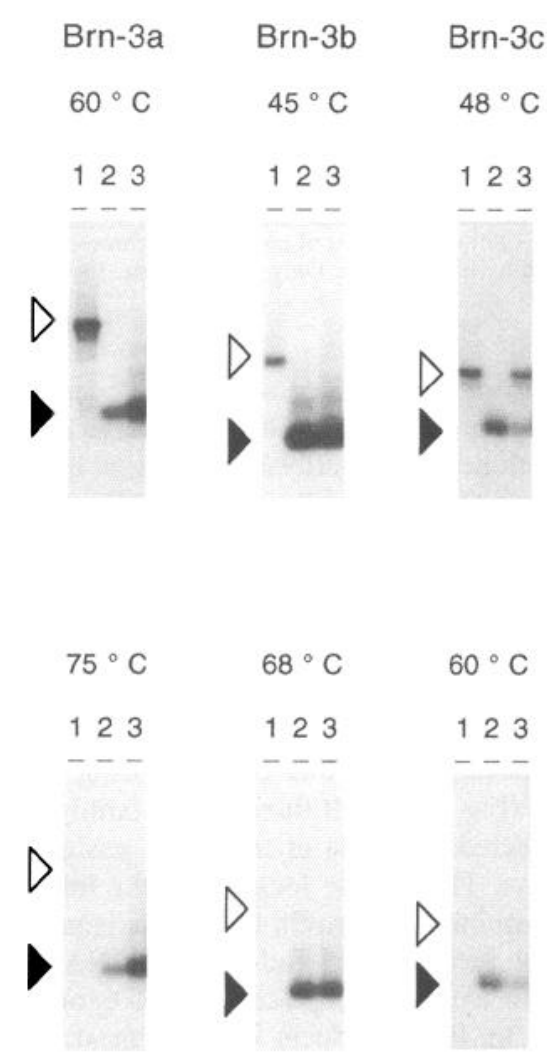

Figure 3. Detection of Brn-3 transcripts in the human retina by RTPCR. A, Schematic diagram of PCR products derived from genomic DNA (open arrowhead) and first strand cDNA (solid arrowhead) for the three Brn-3 genes. The solid lines represent the two exons, and the dashed line represents the intron. The positions of the two PCR primers are indicated by arrows. B, Southern blot analysis of PCR products. For each Brn-3 gene, DNA products were generated by PCR using primers in the two exons as shown in $A$ and the following templates: human genomic DNA (lane 1), a human retina cDNA library (lane 2), and human retina first strand cDNA (lane 3 ). The PCR products were resolved by agarose gel electrophoresis, transferred to nitrocellulose, and hybridized to a 24 base probe that matches the mature mRNA sequence and straddles the site of the intron (i.e., the probe contains the last 12 nucleotides of the first coding exon joined to the first 12 nucleotides of the second coding exon). Filters were washed in $3 \times$ SSC, $1 \%$ SDS at the indicated temperatures. Two autoradiographs are shown for each filter; the upper one was obtained after a low stringency wash and the lower one after a high stringency wash. The open arrowhead indicates the PCR product obtained from the unspliced or genomic template and the solid arrowhead indicates the product obtained from the spliced template.

jections of Texas red-conjugated dextrans (10,000 MW; Molecular Probes) were made in three monkeys. The monkeys were anesthetized with ketamine (20 mg/kg, i.m.) and Nembutal $(15 \mathrm{mg} / \mathrm{kg} / \mathrm{hr}$, i.v.) and mounted in a stereotaxic frame. Using sterile surgical procedures, a small craniotomy was made over the central sulcus and stereotaxical- ly-aimed tungsten microelectrodes were lowered through the cortex into the dorsal thalamus. Multiunit activity was mapped during presentation of visual stimuli, which permitted the borders of the dorsal LGN to be mapped with penetrations spaced $1 \mathrm{~mm}$ apart. The mapping electrode was withdrawn and a multibarrel glass pipette, pulled and filled with $5 \%$ Texas red-dextran in sterile saline, was inserted at previously identified sites in the LGN. After visually evoked responses were again identified, the dextran solution was ejected iontophoretically $(5 \mu \mathrm{A}$, with a $7 \mathrm{sec}$ on/off duty cycle) over a period of $20-25 \mathrm{~min}$. In one experiment, injections were made at each of several sites in both parvocellular and magnocellular layers, and, in a second experiment, at a single site in layer 6 . After all injections were completed, the craniotomy was filled with dental cement and the wound was sutured closed. Two or three weeks later, the monkeys were anesthetized with ketamine and were injected with a lethal dose of Nembutal $(100 \mathrm{mg} / \mathrm{kg}$, i.v. $)$. They were then perfused through the heart with 4 liters of $4 \%$ paraformaldehyde in $0.1 \mathrm{M}$ phosphate buffer $(\mathrm{pH} 7.4)$. The brain and eyes were removed and postfixed in perfusate. Blocks of the LGN were then placed in $20 \%$ buffered sucrose at $4^{\circ} \mathrm{C}$ for several days. They were frozen and cut at $30 \mu \mathrm{m}$, collected serially and mounted on clean slides. Injection sites were identified under a fluorescence microscope.

Preparation of whole-cell protein extracts and fusion proteins with glutathione-S-transferase (GST). Mammalian expression plasmids containing full-length Brn-3b and Oct- 2 coding regions under the control of the cytomegalovirus promotor were as previously described (Tanaka and Herr, 1990; Xiang et al., 1993). These constructs were transiently transfected into $293 \mathrm{~S}$ cells using the calcium phosphate method. Seventy-two hours after transfection, the cells were harvested and lysed by sonication in the following microextraction buffer (Scholer et al. 1989): 20 mм HEPES ( $\mathrm{pH} 8.0$ ), $100 \mathrm{~mm} \mathrm{NaCl}, 0.2 \mathrm{~mm}$ EDTA, 0.5 mм DTT, $25 \%$ glycerol, $0.5 \mathrm{~mm}$ PMSF, $0.5 \mu \mathrm{g} / \mathrm{ml}$ leupeptin, and $1 \mu \mathrm{g} / \mathrm{ml}$ aprotinin. Cell debris was removed by microcentrifugation for 5-10 min and the whole cell protein extracts were stored at $-80^{\circ} \mathrm{C}$.

Fusion proteins between GST and the POU-domains of Brn-3a, Brn$3 \mathrm{~b}, \mathrm{Brn}-3 \mathrm{c}$, and Oct- 1 were generated from PCR products corresponding to codons 253-423 of Brn-3a, 240-410 of Brn-3b, 168-338 of Brn-3c, or $276-443$ of Oct-1. These regions were cloned in frame into the expression vector pGEX-2T (Pharmacia) and the sequences of the inserts verified by DNA sequencing. The GST fusion proteins were purified using glutathione-agarose affinity chromatography to apparent homogeneity as determined by SDS-polyacrylamide gel electrophoresis (Smith and Corcoran, 1991).

Gel mobility shift assay. DNA probes were generated by 5 '-end labeling with $\gamma^{-32}$ P ATP and T4 polynucleotide kinase. Binding reactions were prepared in a final volume of $20 \mu \mathrm{l}$ with the following components: $10 \mathrm{~mm}$ HEPES (pH 7.5), $50 \mathrm{~mm} \mathrm{KCl}, 1 \mathrm{~mm}$ EDTA, $50 \mu \mathrm{g} / \mathrm{ml}$ poly(dI-dC), $0.1 \%$ Triton X-100, 5\% glycerol, $0.1 \mathrm{~mm}$ DTT, $0.1 \mathrm{~mm}$ PMSF, approximately $1 \times 10^{4} \mathrm{cpm}$ of radiolabeled DNA, and the indicated fusion proteins or whole cell protein extracts from transfected $293 \mathrm{~S}$ cells. Competition reactions were prepared as described except for the addition of the desired amount of cold DNA oligonucleotides. The binding reactions and competition reactions were incubated at room temperature for $20 \mathrm{~min}$ and $35 \mathrm{~min}$, respectively. Immediately following the incubation, the bound complexes were separated from the free probe by electrophoresis in 5\% nondenaturing polyacrylamide gels and visualized by autoradiography. The signal intensity was quantitated using a Phosphor-Imager (Molecular Dynamics).

DNA binding site selection. The procedure for DNA binding site selection was adapted and modified from Thiesen and Bach (1990). The template oligonucleotide contained a central region consisting of an equal mixture of all four nucleotides at 15 consecutive positions which was flanked on each side by 18 specific nucleotides that included a BamHI site on one side and an EcoRI site on the other side: 5' GGATGGATCCTGCAGTAC(N) $)_{15}$ AGCTGAGCGAATTCGGTC 3'. In addition, two PCR primers were synthesized which matched the template or its complement within the flanking sequences: A, 5'GGATGGATCCTGCAGTAC-3'; B, 5'GACCGAATTCGCTCAGCT3'. Doublestranded templates were synthesized with the Klenow fragment of DNA polymerase I using the B primer.

For binding site selection, radiolabeled templates were incubated with approximately $100 \mathrm{ng}$ of the GST-Brn-3b POU-domain fusion protein and subjected to gel mobility shift analysis. The bound complexes were localized by autoradiography, and eluted from the dried gel by incubating the gel slice for $3 \mathrm{hr}$ at $37^{\circ} \mathrm{C}$ in $250 \mu \mathrm{l}$ of elution buffer [ 500 $\mathrm{mm} \mathrm{NH}_{4} \mathrm{OAc}, 1 \mathrm{~mm}$ EDTA (pH 8.0)]. Five microliters of the eluted 
Table 1. Segregation of human Brn-3a and Brn-3c genes with human chromosomes in mouse-human hybrid cell lines

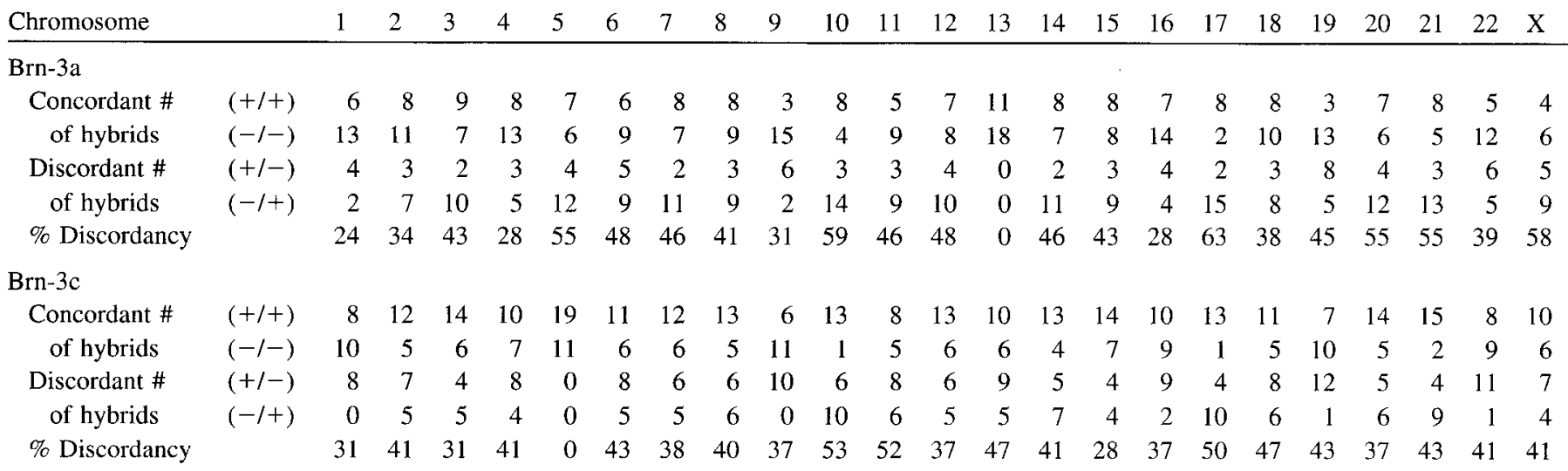

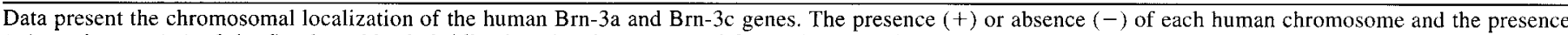

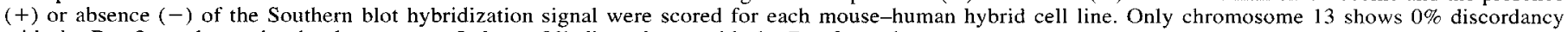
with the Brn-3a probe, and only chromosome 5 shows $0 \%$ discordancy with the Brn-3c probe.

DNA was then PCR amplified using the A and B primers for 30 cycles of $45^{\circ} \mathrm{C}, 2 \mathrm{~min} ; 67^{\circ} \mathrm{C}, 3 \mathrm{~min} ; 94^{\circ} \mathrm{C}, 30 \mathrm{sec}$. After addition of excess primers and fresh Taq polymerase, a final cycle of $94^{\circ} \mathrm{C}, 5 \mathrm{~min} ; 45^{\circ} \mathrm{C}$, $2 \mathrm{~min} ; 67^{\circ} \mathrm{C}, 10 \mathrm{~min}$ was performed to ensure that most of the oligonucleotides were double-stranded homoduplexes. Following separation of the PCR products in a $4 \%$ low-melt agarose gel, they were purified and end-labeled for the next round of selection. After four to eight rounds of selection, the amplified oligonucleotides were digested with BamHI and EcoRI, and ligated into pBluescript (Stratagene) at a low concentration so that most subclones would have only one oligonucleotide insert.

To check the binding of individual cloned segments, single colonies or minicultures were used as templates for PCR amplification using PCR primers A and B, one of which was 5'-end labeled; $3 \%$ of the PCR mixture was utilized directly for binding to the GST-Brn-3b POUdomain by gel mobility shift assay.

\section{Results}

Identification, sequence, and chromosomal locations of the genes encoding Brn-3a and Brn-3C

We previously reported the application of a PCR-based approach (He et al., 1989) to identify cDNA sequences from human retina that encode POU domain transcription factors (Xiang et al., 1993). One POU domain sequence, Brn-3b, was charactcrized in detail and found to be expressed in a subset of retinal ganglion cells. From these experiments, two lines of evidence suggested the existence of additional Brn-3b-like genes. First, genomic Southern blot analysis using the Brn-3b POU domain revealed several hybridizing fragments in vertebrate DNA (Xiang et al., 1993). Second, in addition to the Brn-3b POU-domain PCR product, the original collection of $\mathrm{PCR}$ products from hunlan retina revealed a second POU domain, which shares approximately $95 \%$ amino acid sequence identity with the Brn-3b POU domain. This second POU domain sequence was found to be identical to that of a rat POU domain PCR product referred to as Brn-3a (He et al., 1989; Lillycrop et al., 1992). As the retinaderived sequence is likely to be the human homolog of rat Brn$3 \mathrm{a}$ it will be referred to hereafter as Brn-3a.

To characterize the several $\mathrm{Brn}-3 \mathrm{~b}$ homologous sequences, the Brn-3a and Brn-3b POU domain probes were used to screen both a human genomic DNA library and a human retina cDNA library (Nathans et al., 1986). Three groups of overlapping genomic DNA clones were obtained, encompassing the genes encoding Brn-3a, Brn-3b, and a third Brn-3 gene family member, designated Brn-3c. Two groups of cDNA clones were isolated that derive from the Brn-3a and Brn-3b genes. Shown in Figure 1 are the clones that encompass the Brn-3a and Brn-3c genes; the Brn-3b clones are described in Xiang et al. (1993). Together these clones account for all of the bands on human genomic Southern blots that hybridize under standard conditions to the Brn-3b POU domain probe (Xiang et al., 1993).

Comparison of the Brn-3a and Brn-3c genomic DNA sequences with that of Brn-3b shows significant homology in the two regions corresponding to the Brn-3b open reading frame, and predicts that all Brn-3 family members possess the same intron-exon arrangement, that is, two coding exons linked by a short intron (Fig. 2). In all three Brn-3 family members the intron is predicted to reside at the same position in the protein coding region. The precise location of the intron has been previously determined for Brn-3b by comparison of the nucleotide sequences of genomic and full-length cDNA clones (Xiang et al., 1993). To identify the precise intron-exon junction in Brn$3 a$ and Brn-3c, PCR products were synthesized across this region using as template either human genomic DNA, first strand human retina $\mathrm{cDNA}$, or the human retina cDNA library. In each case a product of the expected size was obtained from the genomic DNA template (Fig. 3, open triangles). A smaller product, consistent with the predicted splicing event, was obtained using the two cDNA templates (Fig. 3, solid triangles). Following agarose gel electrophoresis, the PCR products were blotted onto nitrocellulose and probed with an oligonucleotide probe spanning the predicted junction of the spliced exon sequences. As shown in Figure 3, PCR products derived from both cDNA and genomic DNA templates hybridize to the oligonucleotide probe at low stringency, whereas only products derived from the cDNA templates hybridize at high stringency. To further confirm the predicted splice junction sequence, PCR products derived from amplification of the cDNA templates were cloned and sequenced. For each of the three Brn-3 genes, the amplified segments revealed the predicted splicing event.

Taking into account the intron-exon structure defined above and choosing the initiator methionine that corresponds most closely to the putative initiator methionine of Brn-3b, the genomic DNA sequences contain open reading frames of 423 amino acids for Brn-3a and 338 for Brn-3c, corresponding to molecular masses of $47 \mathrm{kDa}$ and $37 \mathrm{kDa}$, respectively (Fig. $2 A$ ). Each Brn-3 protein has a highly conserved DNA binding POU 


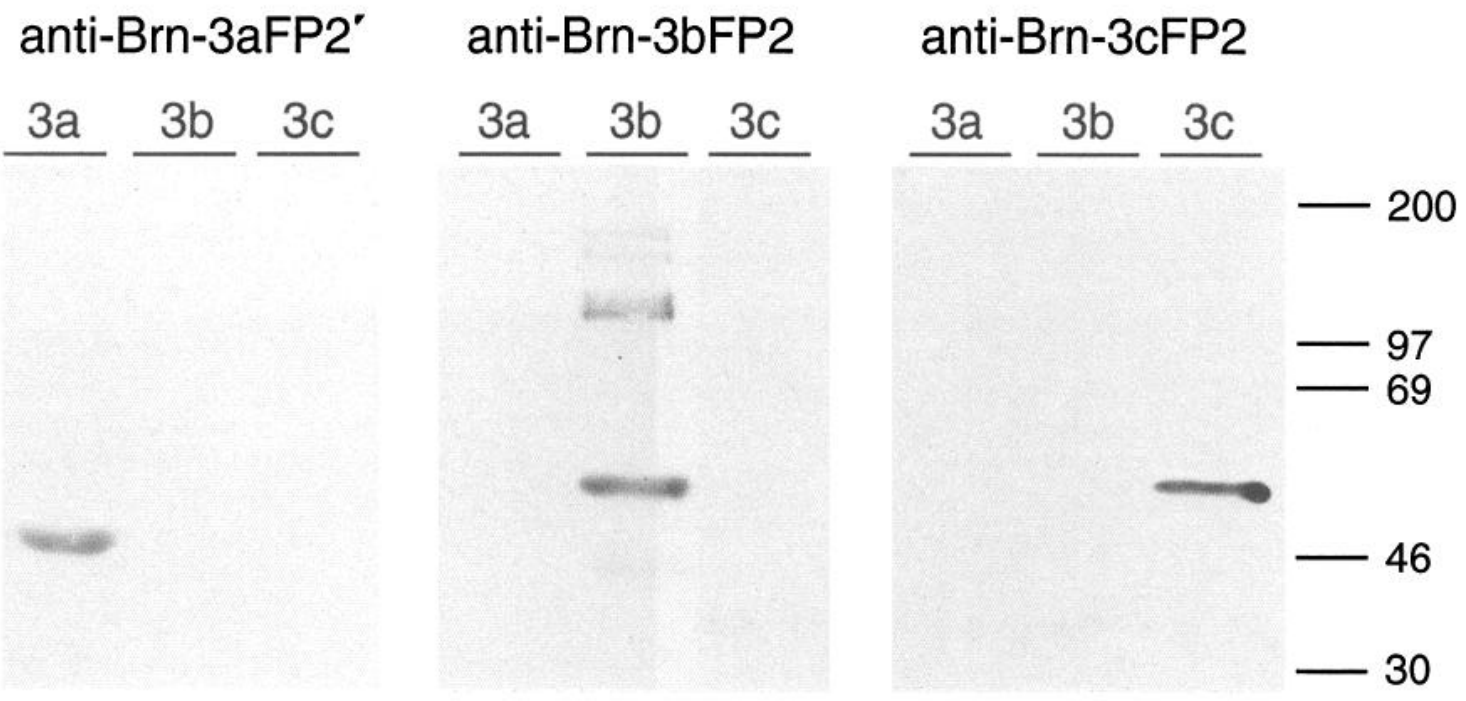

Figure 4. Specificity of anti-Brn-3 antibodies determined by immunoblot analysis. Fusion proteins between MBP and Brn-3a FP2', Brn-3b FP2, or Brn-3c FP2 (indicated above each lane by $3 a, 3 b$, or $3 c$ ) were resolved by SDS-PAGE, transferred to nitrocellulose and immunoreacted with affinity-purified antibodies against Brn-3a FP2' (left), Brn-3b FP2 (center), or Brn-3c FP2 (right). Ten micrograms of each fusion protein was used for the blot that was immunoreacted with anti-Brn-3a FP2' antibodies; $1.5 \mu \mathrm{g}$ of each fusion protein was used for the other two blots. Protein molecular mass markers are indicated to the right. The band of lower mobility in the Brn-3b lane is presumed to arise from protein aggregation.

domain at its carboxyl-terminus, which displays approximately 95\% sequence identity with each of the other Brn-3 POU domains. The region amino-terminal to the POU domain shows stretches of lower overall sequence homology interrupted by runs of one or a few amino acids (Fig. 2). Particularly notable in this region is the upstream homology domain (UHD) conserved among all the Brn-3 members and other class IV POU family members including Unc-86 and tI-POU/I-POU (Fig. 2B; Finney et al., 1988; Treacy et al., 1991, 1992; Xiang et al., 1993). The functional significance of the UHD is unknown but it may form an $\alpha$-helix based on secondary structure prediction.

A cDNA clone isolated from the human Jurkat T-cell line and referred to as Oct-T1 (Bhargava et al., 1993) corresponds exactly to the human Brn-3a sequence reported here. A second human POU domain gene identified in a genomic DNA library and referred to as RDC-1 (Collum et al., 1992) almost certainly corresponds to Brn-3a despite significant discrepancies between the amino acid sequence reported by Collum et al. and that reported here. We attribute these differences to sequencing errors by Collum et al. Several recently reported mouse sequences-referred to as Brn-3.0/Brn-3a, Brn- 3.2/Brn-3b, and Brn-3.1/Brn-3c-are likely to represent homologs of human Brn-3a, Brn-3b, and Brn3c, respectively (Gerrero et al., 1993; Theil et al., 1993; Turner et al., 1994). At the amino acid level the corresponding pairs of human and mouse sequences show $98 \%$ identity. As shown in Figure 1, two partial Brn-3a cDNA clones were isolated from the human retina cDNA library, one (hs204) with a longer 3' untranslated region and the other (hs210) with a shorter one followed by a polyA tract. Northern blotting has revealed two forms of Brn-3a/RDC-1 transcripts $(\sim 2.0 \mathrm{~kb}$ and $\sim 4.0 \mathrm{~kb})$ in the human eye and in the CHP100 neuroepithelioma cell line (Collum et al., 1992) and two forms of mouse Brn-3.0 transcripts $(\sim 2.4 \mathrm{~kb}$ and $\sim 3.8 \mathrm{~kb})$ were found in rat trigeminal ganglia (Gerrero et al., 1993). It is unclear in the present instance whether utilization of alternative polyadenylation sites has any functional consequence.

In many cases, members of a gene family are clustered at a single locus following their duplication and divergence. To test this possibility for the Brn-3 genes, we mapped the chromosomal locations of the Brn-3a and Brn-3c genes by Southern blot hybridization of DNA from a panel of mouse-human somatic cell hybrids (Table 1). Only human chromosomes 13 and 5 show $100 \%$ concordance with the hybridization bands derived from Brn-3a and Brn-3c, respectively; in earlier work the Brn-3b gene was found to reside on human chromosome 4 (Xiang et al., 1993). Thus, none of the members of the Brn-3 gene family are linked. We note that this mapping further confirms the identity of RDC-1 and Brn-3a, as RDC-1 is also located on chromosome 13 (Collum et al., 1992).

Characterization of antibodies specific for Brn-3a, Brn-3b, and Brn-3c

As described above, a reverse transcriptase-PCR assay revealed the presence in human retina of spliced RNA transcribed from each of the Brn-3 genes. These data are in agreement with the results of RNA slot blot experiments showing hybridization of probes derived from $\mathrm{Brn}-3 \mathrm{~b}$ and $\mathrm{Brn}-3 \mathrm{c}$ to bovine retina RNA (Xiang et al., 1993, and data not shown). To examine at high resolution the cellular distribution of Brn-3a and Brn-3c proteins, we generated rabbit polyclonal antibodies specific to each protein using a strategy similar to that reported earlier for Brn3b (Xiang et al., 1993). An anti-Brn-3c antiserum was produced using an immunogen containing the bacteriophage T7 gene 10 product fused to a polypeptide containing amino acids 110-180 (Brn-3c FP2), which corresponds to the same region from Brn$3 \mathrm{~b}$ that was previously used as an immunogen by Xiang et al. (1993; Brn-3b FP2). Anti-Brn-3a antisera were similarly generated using gene 10 fusion proteins with either a Brn-3a polypeptide containing amino acid residues 28-99 (Brn-3a FP1) or a Brn-3a polypeptide containing amino acid residues 186-224 (Brn-3a FP2'; Fig. 2A). Because the high G-C content of the Brn-3a FP2' region precluded its expression in E. coli, a DNA segment encoding the same polypeptide sequence was chemically synthesized using codons with a higher A-T content. Each 

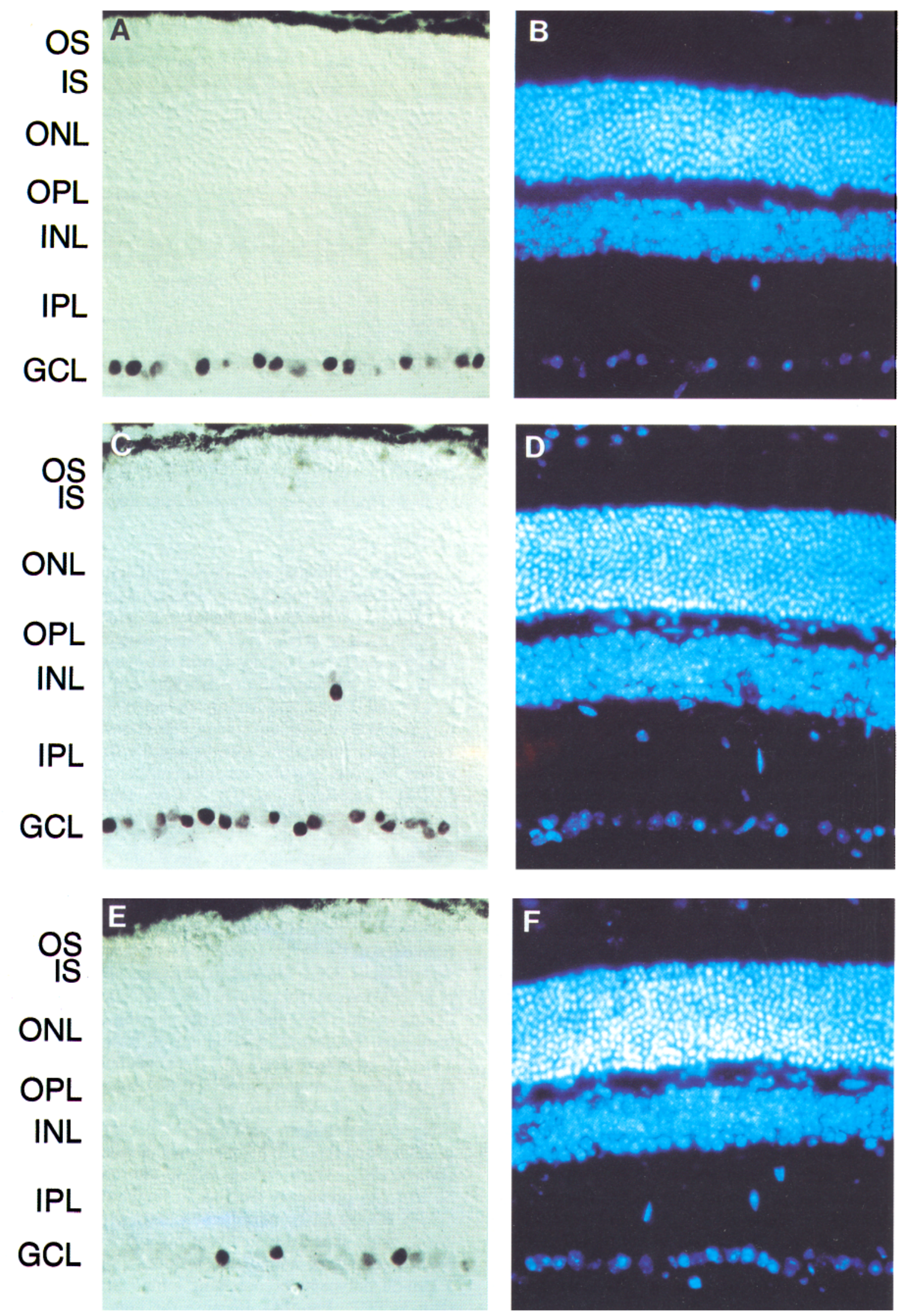

Figure 5. Anti-Brn-3a, Brn-3b, and Brn-3c immunoreactivity in the mouse retina. To simultaneously localize Brn-3 proteins and visualize nuclei, mouse retina sections were double stained with anti-Brn-3a and DAPI $(A, B)$, anti-Brn-3b and DAPI $(C, D)$, or anti-Brn-3c and DAPI $(E, F)$. Note that the purple HRP product of the immunostaining reaction partially quenches DAPI fluorescence when both are present in the same nucleus. $O S$, 

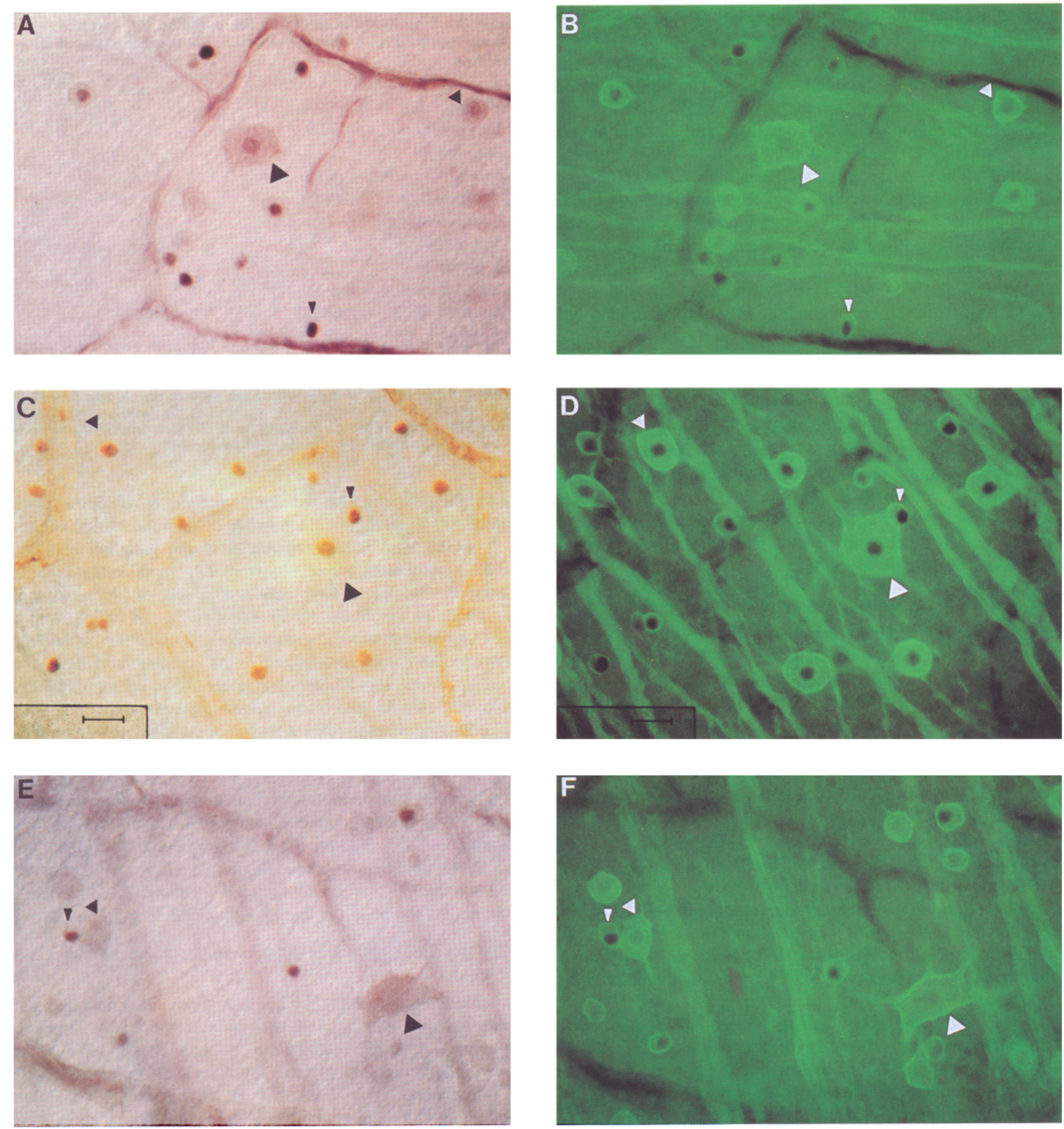

Figure 6. Anti-Brn-3a, Brn-3b, and Brn-3c immunoreactivity in cat retinal ganglion cells. Pieces of midperipheral cat retinae were flat-mounted and double immunostained with monoclonal antibody AB5 and anti-Brn-3a $(A, B)$, anti-Brn-3b $(C, D)$, or anti-Brn-3c $(E, F)$. AB5 immunostaining was visualized with a fluorescein conjugated second antibody $(B, D, F)$; anti-Brn-3a, Brn-3b, and Brn-3c immunostaining was visualized with the ABC-peroxidase method $(A, C, E)$. The large, medium, and small arrowheads point, respectively, to $\alpha, \beta$, and $\gamma$ ganglion cells. Note that the fiberlike staining in $A, C$, and $E$ results from endogenous peroxidase activity in blood vessels. Scale bar, $25 \mu \mathrm{m}$. 
antiserum was affinity-purified using the immunizing Brn-3 polypeptide fused to the $E$. coli maltose binding protein (MBP).

In the Brn-3b and Brn-3c FP2 region, the three Brn-3 proteins show 38-41\% amino acid sequence identity. The shorter Brn-3a $\mathrm{FP} 2$ ' region is contained within the Brn-3b and Brn-3c FP2 region, and in this region the three sequences share 23-38\% amino acid identity (Fig. 2A). The FP1 region shows $76-79 \%$ amino acid identity. The specificities of anti-Brn-3c FP2 and anti-Brn3a FP2' antibodies, together with that of the previously generated antibody against Brn-3b FP2 (Xiang et al., 1993), were assessed by Western blotting using equal quantities of MBP fusion proteins containing Brn-3a FP2' ( 56 kDa), Brn-3b FP2 $(\sim 60$ $\mathrm{kDa})$, and Brn-3c FP2 ( $\sim 60 \mathrm{kDa})$. Each of the affinity-purified antibodies bound to the corresponding MBP fusion protein but showed no detectable binding to the other two proteins (Fig. 4), demonstrating that these antibodies are specific. Further evidence for this specificity comes from the unique staining patterns observed with each antibody as described below and for Brn-3b in Xiang et al. (1993). An analogous Western blot using affinitypurified anti-Brn-3a FP1 antibody and the three FP1 MBP fusion proteins showed strong binding to the Brn-3a fusion protein and weak binding to the Brn-3b and Brn-3c fusion proteins (data not shown). Unless otherwise noted all of the immunostaining experiments described below were performed with affinity purified anti-Brn-3a FP2', anti-Brn3b FP2, and anti-Brn-3c FP2.

\section{Distribution of Brn-3 proteins in the mouse retina}

Immunostaining of sections of mouse retina using anti-Brn-3a and anti-Brn-3c antibodies showed that both labeled a subpopulation of cells in the ganglion cell layer, although the anti-Brn$3 \mathrm{c}$ antibody clearly stained fewer cells (Fig. $5 A, E$ ). This pattern is reminiscent of that seen with anti-Brn-3b antibodies (Fig. $5 C$ and Xiang et al., 1993). Close inspection of Figure 5 shows significant heterogeneity in nuclear staining intensity with each of the three antibodies. Double labeling with the fluorescent dye 4', 6-diamidino-2-phenylindole (DAPI), which visualizes all of the nuclei, localizes the antibody staining to the nuclei, a subcellular location consistent with the Brn-3 proteins functioning as transcription factors. As reported earlier for anti-Brn-3b antibodies (Xiang et al., 1993), antibodies against Brn-3a and Brn$3 \mathrm{c}$ stained only the ganglion cell layer in monkey, rabbit, cat, and chicken retinas. (Rabbit and chicken data are not shown.) Double labeling experiments using AB5, a monoclonal antibody that specifically labels all ganglion cells in rabbit and cat retinae (Fry et al., 1985), and either anti-Brn-3a or anti-Brn-3c show that in rabbit and cat retinae the cells expressing Brn-3a and Brn-3c are ganglion cells (see below). With each of the Brn-3 antibodies occasional immunostained cells were observed in the inner nuclear or inner plexiform layers as seen in Figure $5 C$; these are presumed to represent displaced ganglion cells. In the mouse retina the frequency of cells that stained with each of the antibodies appears to be approximately constant across the retina. In the descriptions that follow we will refer to the immunolabeled cells as ganglion cells, even in those species (such as the mouse) where this has not been unequivocally demonstrated

The three subpopulations of mouse retinal ganglion cells immunoreactive with anti-Brn-3a, Brn-3b, or Brn-3c antibodies could be mutually exclusive, partially overlapping, or completely overlapping. To distinguish these possibilities, we counted the number of nuclei stained in the mouse retina with each of the anti-Brn-3 antibodics alone and, in adjacent scctions, with cach of the three pairwise mixtures of anti-Brn-3 antibodies (Table
Table 2. Percentage of nuclei in the ganglion cell layer of the mouse retina that are immunoreactive for combinations of Brn-3 proteins

$\begin{array}{ll}\text { Experiment } 1(n=700-900) & \\ \text { Anti-Brn-3a } & 36 \% \\ \text { Anti-Brn-3b } & 35 \% \\ \text { Anti-Brn-3a }+ \text { anti-Brn-3b } & 37 \% \\ \text { Experiment 2 }(n=700-800) & \\ \text { Anti-Brn-3a } & 35 \% \\ \text { Anti-Brn-3b } & 36 \% \\ \text { Anti-Brn-3c } & 15 \% \\ \text { Anti-Brn-3a }+ \text { anti-Brn-3c } & 36 \% \\ \text { Anti-Brn-3b }+ \text { anti-Brn-3c } & 36 \%\end{array}$

Degree of overlap of anti-Brn-3a, Brn-3b, or Brn-3c immunoreactive ganglion cells in the mouse retina. Adjacent mouse retina sections were immunolabeled with anti-Brn-3a, anti-Brn-3b, or anti-Brn-3c, or double labeled with various pain wise conbinations of antibodies. Each section was double stained with DAPI to determine the total number of nuclei in the ganglion cell layer. The percentage of cells in the ganglion cell layer that were immunostained is tabulated. $n$, total number of nuclei counted per section.

2). In these experiments the retina sections were double-labeled with DAPI to quantitate the number of immunostained nuclei as well as the total number of nuclei in the ganglion cell layer. Table 2 quantitates the results from two representative experiments; similar results were obtained in several independent experiments. In the mouse retina, anti-Brn-3a and anti-Brn-3b antibodies together stained approximately $37 \%$ of the nuclei in the ganglion cell layer. In adjacent retina sections, anti-Brn-3a antibodies alone stained approximately $36 \%$ of ganglion cells while anti Brn 3b antibodies stained approximately 35\% (Table 2 ), indicating that the subpopulation of ganglion cells expressing Brn-3a largely overlaps that expressing Brn-3b. Anti-Brn-3c antibodies alone labeled approximately $15 \%$ of nuclei within the ganglion cell layer, and the percentage of labeled cells observed when it was combined with either anti-Brn3a or anti-Brn3b antibodies $(\sim 36 \%)$ was close to that observed with either antiBrn-3a or anti-Brn-3b antibodies alone (Table 2 ). These data indicate that in the mouse retina the cells expressing Brn-3c constitute a subset of those expressing both Brn-3a and Brn-3b.

\section{Differential distribution of Brn-3 proteins in cat retinal ganglion cells}

In the cat retina, ganglion cells have been classified into three major groups- $\alpha, \beta$, and $\gamma$-that have, respectively, large, medium, and small cell bodies (Boycott and Wassle, 1974). These three groups correspond to the physiolngically defined $\mathrm{Y}, \mathrm{X}$, and W types, respectively (Cleland et al., 1975; Saito, 1983; Fukuda et al., 1985). To determine the identities of the cat retinal ganglion cells that contain each of the Brn-3 proteins, we immunostained flat-mounts of cat retinae using each of the anti-Brn-3 antibodies and a monoclonal antibody, AB5, that had previously been shown to specifically label all ganglion cells and their processes in the cat retina, thereby permitting a clear visualization of $\alpha, \beta$, and $\gamma$ cell types (Fry et al., 1985; Fry and Lam, 1986). As observed by Fry and colleagues, large-, medium-, and smallsized ganglion cells were labeled with AB5 and were clearly distinguishable (Fig. 6). A quantitative analysis of soma diameters among AB5-labeled ganglion cells in the mid-peripheral retina revealed the expected division into $\alpha, \beta$, and $\gamma$ subgroups (Fig. 7). As seen in Figure 6, $A$ and $B$, and Figure $7 A$, strong anti-Brn-3a immunoreactivity is confined to $\sim 70 \%$ of the $\gamma$ 

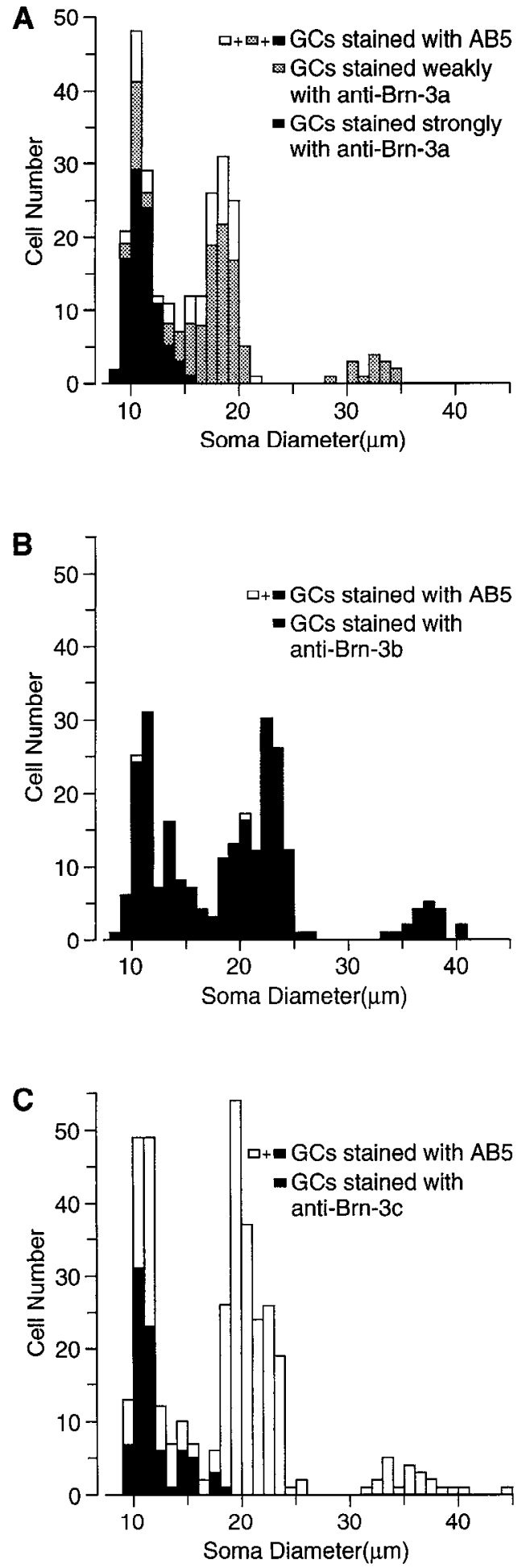

Figure 7. Size distribution of ganglion cells expressing Brn-3 proteins in the cat retina. From the experiment shown in Figure 6, the number and sizes of AB5-labeled ganglion cells from a small retinal area were determined. For each AB5-labeled cell, the degree of anti-Brn-3a, Brn$3 b$, or Brn-3c immunoreactivity was recorded. Anti-Brn-3a immunoreactive cells could be roughly divided into two classes, strong and weak, according to their nuclear staining intensity (see Fig. 6A,B). cells. We also consistently observe weak anti-Brn-3a immunoreactivity in all $\alpha$ cells and in $\sim 70 \%$ of the $\beta$ cells (Figs. $6 A, B$; $7 A$ ). By contrast, the anti-Brn-3b antibody stains all of the AB5labeled cells with a more uniform intensity, indicating that the Brn-3b protein accumulates to a similar level in $\alpha, \beta$, and $\gamma$ ganglion cells (Figs. $6 C, D ; 7 B$ ). Anti-Brn-3c antibodies stain $\sim 50 \%$ of the $\gamma$ cells, and do not label either $\alpha$ or $\beta$ cells (Figs. $6 F, F ; 7 C$ ). As seen in Figure $6, F$ and $F$, the anti-Rrn- $3 c$ antibodies gave some cytoplasmic staining, especially among $\alpha$ ganglion cells. Because visualization of the HRP reaction product using the anti-Brn-3c antibody required longer peroxidase incubation times than did the anti-Brn3a or anti-Brn-3b antibodies, the cytoplasmic staining may represent nonspecific background.

\section{Differential distribution of Brn-3 proteins in macaque retinal ganglion cells}

In the primate retina different types of ganglion cells are distinguished by their abundance, morphology, and topographic distribution. The physiologically defined P-cells correspond morphologically to midget ganglion cells, constitute approximately $80 \%$ of ganglion cells, and have small cell bodies and small dendritic fields (Perry et al., 1984; Rodieck et al., 1985; Watanabe and Rodieck, 1989; Dacey, 1993). The physiologically defined M-cells correspond morphologically to the parasol cells, constitute approximately $10 \%$ of ganglion cells, and have large cell bodies and large dendritic fields (Rodieck et al., 1985; Watanabe and Rodieck, 1989; Silveria and Perry, 1991). A number of less common cell types comprise the remaining $10 \%$ of ganglion cells (Perry and Cowey, 1984; Rodieck and Watanabe, 1993). Both midget and parasol cells are distributed in a manner that roughly parallels the overall distribution of ganglion cellsthat is, they are most concentrated near the fovea and fall to progressively lower density in the periphery. The relative density of parasol cells remains constant at approximately $10 \%$ of ganglion cells throughout the retina (Perry et al., 1984; Silveria and Perry, 1991), whereas current evidence suggests that the midget cell density falls more steeply with eccentricity (Dacey, 1993).

As a first step in determining the identities of the Brn-3 expressing ganglion cells, we examined their number and topographic distribution across the macaque retina. A strip of retina containing the horizontal meridian from one macaque retina was divided into 14 segments of equal width and cryostat sections from each segment were analyzed. Sections were stained with each of the anti-Brn-3 antibodies and with DAPI to quantitate both the number of immunolabeled nuclei and the total number of nuclei in the ganglion cell layer. As seen in Figure $8 A$ for anti-Brn-3a immunoreactivity, immunolabeling was confined to nuclei in the ganglion cell layer. A similar distribution was observed for anti-Brn-3b immunolabeling. Figure $8 A$ also illustrates the characteristic heterogeneity of staining intensity observed with anti-Brn-3a and anti-Brn-3b antibodies. When both strongly and weakly stained cells are counted, then staining with anti-Brn-3a alone, anti-Brn-3b alone, or a mixture of the two (as described above for the mouse retina) produces approximately the same number of labeled cells (Fig. $8 B$ ). Thus, in the macaque retina, as in the mouse retina, these two proteins appear to colocalize. The anti-Brn-3c antibodies revealed only weak staining of occasional nuclei within the ganglion cell layer (data not shown), a result that could reflect either the low abundance of this protein in the retina or inefficient immunostaining with these antibodies. The topographic distribution of these cells has not been determined. 

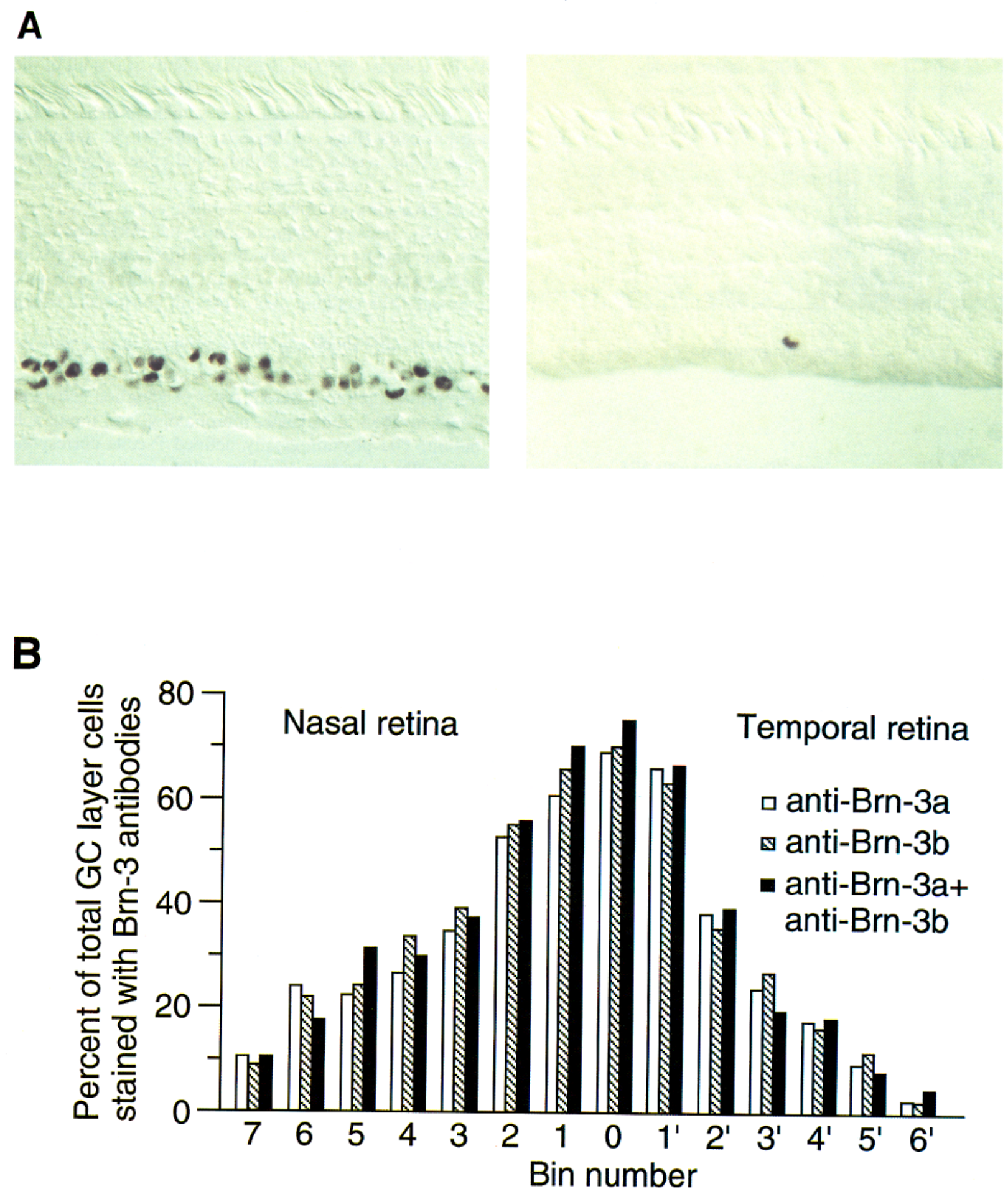

Figure 8. Distribution of anti-Brn-3a and Brn-3b immunoreactivity among ganglion cells in the macaque retina. A, Sections from the central (left) and peripheral (right) macaque retina were immunostained with anti-Brn-3a. Magnification, $400 \times$. B, Histogram of the percentage of total ganglion cell $(G C)$ layer nuclei immunostained with anti-Brn-3a, anti-Brn-3b, or with both anti-Brn-3a and anti-Brn-3b in sections through a series of adjacent segments along the horizontal meridian of the macaque retina. Nuclei were visualized by DAPI staining. Bin 0 , the segment containing the fovea: $\operatorname{bin} 7$, the edge of the nasal retina; bin $6{ }^{\prime}$, the edge of the temporal retina.

In contrast to the approximately uniform distribution of immunolabeled cells across the mouse retina, both the absolute and the relative densities of anti-Brn-3a and anti-Brn-3b immunolabeled cells in the macaque retina show a progressive decrease with eccentricity (Fig. 8). The topographic distribution of im- munolabeled cells roughly resembles the overall distribution of ganglion cells in the macaque retina (Rodieck, 1988). In Figure 8 we have plotted as a function of eccentricity the relative density of immunolabeled cells, that is, the percent of all nuclei in the ganglion cell layer that are immunolabeled. A decline in 
relative density with increasing eccentricity is characteristic of ganglion cells, whereas an increase in relative density is characteristic of displaced amacrine cells (Wassle et al., 1989). The distribution in Figure 8 clearly implies that the labeled cells correspond to ganglion cells. To estimate from these data the fraction of ganglion cells that are immunolabeled, it is necessary to correct for the presence of displaced amacrine cells in the ganglion cell layer as a function of position along the horizontal meridian. In the central retina, displaced amacrine cells represent an insignificant fraction of the cells in the ganglion cell layer; in the peripheral nasal retina they represent at least one-third of the cells in the ganglion cell layer; and in the peripheral temporal retina they increase to a maximum density approximately five times that of the ganglion cells (see Fig. 3 of Wassle et al., 1989). Applying these corrections to the data in Figure 8 reveals a distribution of immunolabeled ganglion cells that peaks in the parafoveal region at greater than $70 \%$ and drops at both nasal and temporal peripheries to approximately $15 \%$. In the nasal retina the relative number of immunolabeled cells falls more steeply with eccentricity than would be expected for all ganglion cells as calculated by Wassle et al (1989). This discrepancy either represents a group of ganglion cells that are not immunolabeled or arises from a methodologic difference possibly related to a difference in the angle of the meridional section reported by Wassle et al. (1989) and that reported here.

To further characterize the ganglion cells expressing Brn-3a and $\mathrm{Brn}-3 \mathrm{~b}$ in the macaque retina, we immunostained retinae that were retrogradely labeled by iontophoretic injection of Texas Red-conjugated dextran into both the parvocellular and magnocellular layers of the LGN as determined by examining the LGN by fluorescence microscopy (data not shown). Quantitative analysis of soma diameter and immunolabeling was performed within a small $\left(\sim 2 \mathrm{~mm}^{2}\right)$ region of midperipheral retina. As seen in Figures 9 and 10, retrograde labeling generated a bimodal distribution of soma diameters, with a smaller class (soma diameter 7-13 $\mu \mathrm{m}$ ) and a larger class (soma diameter 13-20 $\mu \mathrm{m}$ ) that presumably correspond to $\mathrm{P}$ and $\mathrm{M}$ ganglion cells, respectively. (We note that the relative abundance of these two classes among the retrogradely labeled cells reflects the locations of tracer injection within the LGN rather than the actual ratios of these cell types within the retina.) Immunostaining of the flatmount retina with either anti-Brn-3a or anti-Brn-3b antibodies showed that nearly all of the retrogradely labeled ganglion cells could be immunolabeled to some degree by both antibodies. As described above for staining of sections, anti-Brn-3a and antiBrn-3b antibodies were consistently observed to produce a range of staining intensities among different ganglion cells in the flatmount preparation (Fig. 9). As shown in the histogram in Figure 10 , strong immunolabeling with anti-Brn-3a antibodies was confined to $\sim 10 \%$ of the small cell population, with almost all of the remaining backfilled ganglion cells showing weak immunolabeling. By contrast, $\sim 85 \%$ of the small cells were found to label strongly with anti-Brn-3b antibodies, with almost all of the remaining backfilled cells showing weak immunolabeling.

In a second backfilling experiment, Texas red-conjugated dextran was injected into layer 6 of the macaque LGN, a parvocellular layer that projects to the contralateral retina (Fig. $11 A)$. In this experiment the backfilled ganglion cells were located exclusively within a small parafoveal region in the contralateral retina, consistent with the observed injection site. As seen in Figures 8 and $11 B-E$, immunostaining of this region of the retina shows a high density of Brn-3a and Brn-3b immu-
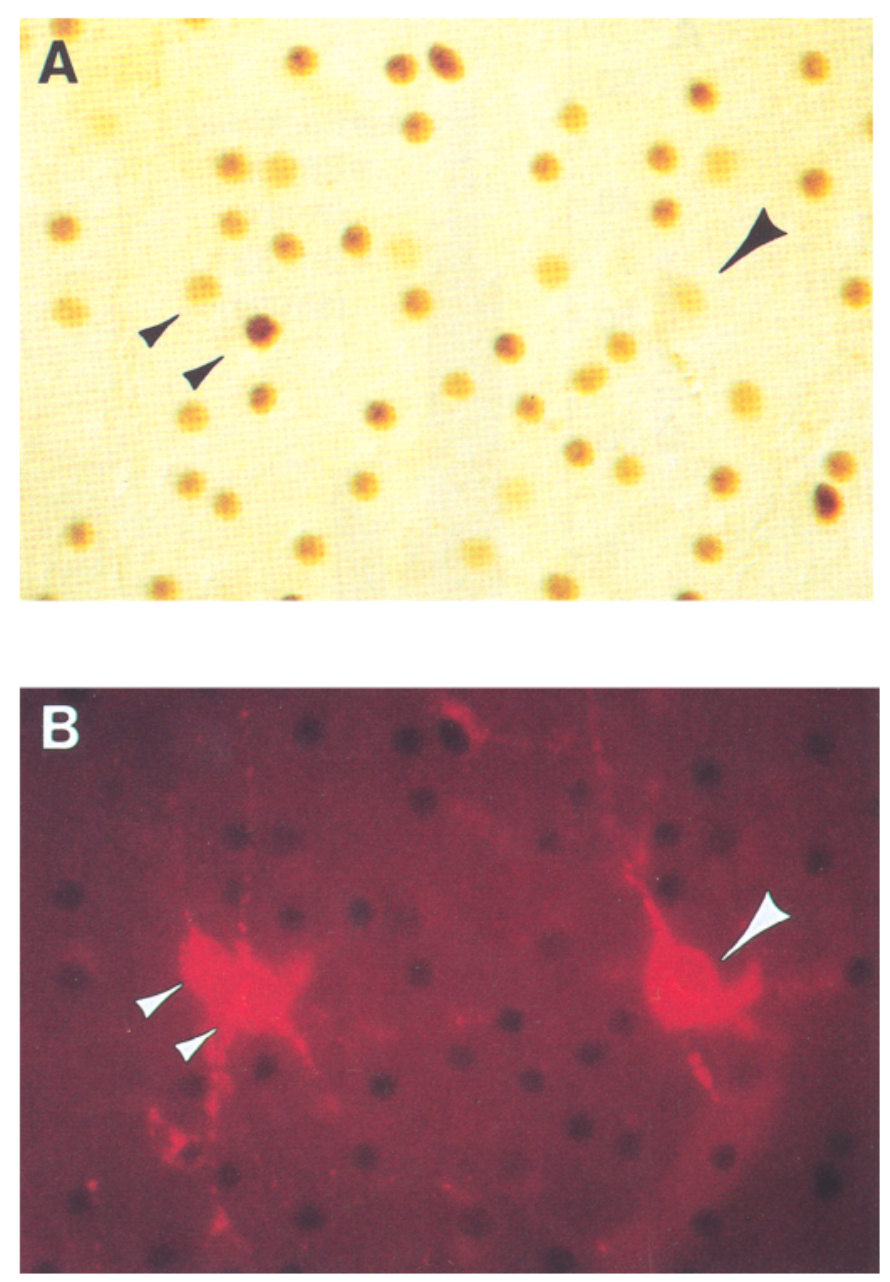

Figure 9. Anti-Brn-3b immunolabeling of backfilled macaque retinal ganglion cells. A macaque retina was immunostained with anti-Brn-3b, following retrograde transport of Texas red-conjugated dextran from an injection that included both the parvocellular and magnocellular layers of the LGN. A, Anti-Brn-3b immunoreactivity visualized with HRP. $B$, Texas red fluorescence. The large arrowhead points to a large backfilled cell, and the small arrowheads point to two smaller backfilled cells. Magnification, $400 \times$.

noreactive cells. When both strongly and weakly immunoreactive cells were summed, 45 of 46 backfilled cells were observed to be labeled with anti-Brn-3a antibodies, and 109 of 110 backfilled cells were observed to be labeled with anti-Brn-3b antibodies. Thus all or nearly all P-type ganglion cells are stained to some degree with anti-Brn-3a and anti-Brn-3b antibodies, a pattern consistent with that obtained in the first backfilling experiment described above.

In a third approach, ganglion cells in the macaque retina that were labeled with anti-Brn-3a and anti-Brn-3b antibodies were characterized by double immunostaining with a monoclonal antibody, SMI-32, which recognizes a nonphosphorylated epitope on the neurofilament $\mathrm{H}$ chain and specifically stains large ganglion cells and their nerve fibers (Nixon et al., 1989). The results of this double labeling experiment were consistent with the observations described above with retrogradely labeled ganglion cells. Fewer than one-quarter of the SMI-32-negative cells stained strongly with anti-Brn-3a antibodies, and approximately $97 \%$ of the SMI-32-labeled cells were stained weakly with the 

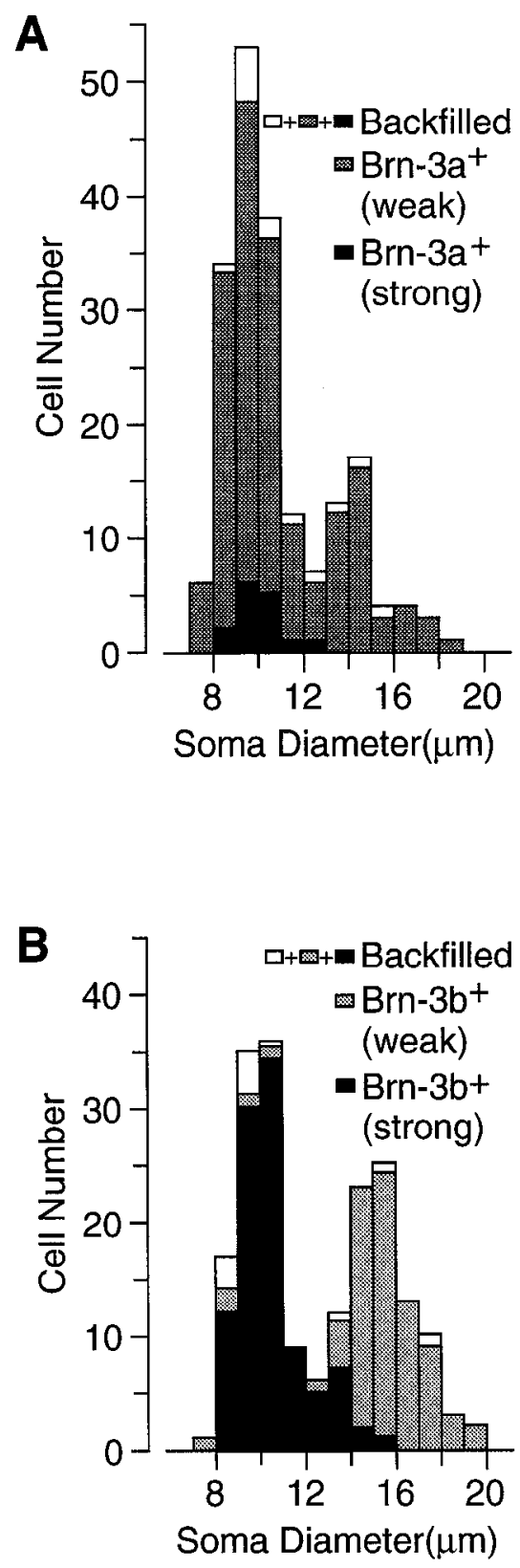

Figure 10. Size distribution of backfilled macaque retinal ganglion cells scored for anti-Brn-3a and Brn-3b immunoreactivity. From the experiment shown in Figure 9, the number and size of backfilled ganglion cells from a retinal area $\sim 2 \mathrm{~mm}^{2}$ were determined. For each backfilled cell, the degree of anti-Brn-3a or Brn-3b immunoreactivity was recorded. In both cases immunoreactive cells could be roughly divided into two classes, strong and weak, according to their nuclear staining intensity. As shown in Figure 12, this division is a relative one-the cells that are weakly labeled with anti-Brn-3a stain with greater intensity than those cells that are weakly labeled with anti-Brn-3b.

anti-Brn-3a antibody and (Fig. 12A,B). Most of the SMI-32negative cells most stained strongly with anti-Brn-3b antibodies, and all of the SMI-32-labeled cells were stained weakly with the anti-Brn-3b antibody (Fig. 12C,D).

These data imply that in the macaque retina, most or all of the large ganglion cells (the parasol or M-type ganglion cells) and the vast majority of the small ganglion cells (the midget or P-type ganglion cells) contain a low level of the Brn-3a protein. However, the Brn-3a protein is present at a high level in a sub- population of small ganglion cells. By contrast, the Brn-3b protein is present at low levels in most or all of the parasol or M-type ganglion cells and at high levels in most or all of the midget or P-type ganglion cells.

\section{Distribution of Brn-3 proteins in somatosensory ganglia and the brain}

In the dorsal root and trigeminal ganglia of adult mice, each of the anti-Brn-3 antibodies stained a subset of nuclei (Fig. 13). Interestingly, the number of labeled cells differed greatly with the different antibodies. Anti-Brn-3a antibodies labeled most of the neurons in the two ganglia; anti-Brn-3b antibodies labeled fewer than $50 \%$ of the neurons; and anti-Brn-3c antibodies labeled only occasional cells (Fig. 13). At present, the functional identities of these neuronal populations are not known. Consistent with these observations, Brn-3a/3.0 mRNA has been shown by RNAse protection to be about 10 -fold more abundant than Brn-3b/3.2 mRNA in the P30 mouse trigeminal ganglion (Turner et al., 1994), and in situ hybridization with a Brn-3a-specific probe produces a more uniform signal than does a Brn-3c-specific probe in embryonic rat dorsal root ganglia (Ninkina et al., 1993). In the adult mouse spinal cord, both anti-Brn-3a antibodies and anti-Brn-3b antibodies weakly labeled a small number of neurons in the dorsal horn; labeling was not detected with anti-Brn-3c antibodies (data not shown). As reported earlier for anti-Brn-3b antibodies (Xiang et al., 1993), both anti-Brn-3a and anti-Brn-3c antibodies failed to stain a variety of non-neural tissues including liver, kidney, heart, and skeletal muscle (data not shown). This observation is consistent with a previous RNA slot blot analysis in which a Brn-3b POU-domain probe that crosshybridizes to each of the Brn-3 sequences failed to hybridize to RNAs from a variety of non-neural tissues (Xiang et al., 1993).

A complete set of coronal sections from an adult mouse brain were immunostained with the anti-Brn- $3 \mathrm{c}$ antibody to investigate its expression in the brain. While no labeling was observed in the cerebral cortex, pons, medulla, or cerebellum, a small number of anti-Brn-3c immunoreactive cells were found in the midbrain (Fig. 14). A population of weakly labeled and sparsely distributed cells were seen in the deep layers of the superior colliculus (Fig. 14A). In the adjacent region of the periaqueductal grey, a diffuse group of cells were more strongly stained (Fig. 14A,C). Anti-Brn-3c antibodies also labeled a group of cells in a wedge-like cluster in the recess of the inferior colliculus (Fig. 14B,D). The distribution of cells in the superior colliculus and periaqueductal gray that express Brn-3c is roughly similar to that reported earlier for Brn-3b, although the latter is expressed in considerably more cells and at levels that are more nearly equal in the two areas (Xiang et al., 1993). Anti-Brn-3c antibodies did not label the interpeduncular nucleus of the midbrain or the area postrema region in the medulla, the two other brain regions in which anti-Brn-3b immunolabeling was observed (Xiang et al., 1993; data not shown).

The distribution of Brn-3a protein in the brain could not be defined with the available antibodies. The anti-Brn3a FP2' antibody stained a large number of cells in many regions of the mouse brain and in one region of macaque occipital cortex that was tested. This immunolabeling pattern appears to represent adventitious binding to another nuclear antigen based on the lack of such staining with anti-Brn3a FPI antibodies (data not shown). Although the anti-Brn-3a FP1 antibody labels retinal ganglion cells and trigeminal and dorsal root ganglion neurons in a pattern consistent with that obtained using the anti-Brn-3a 

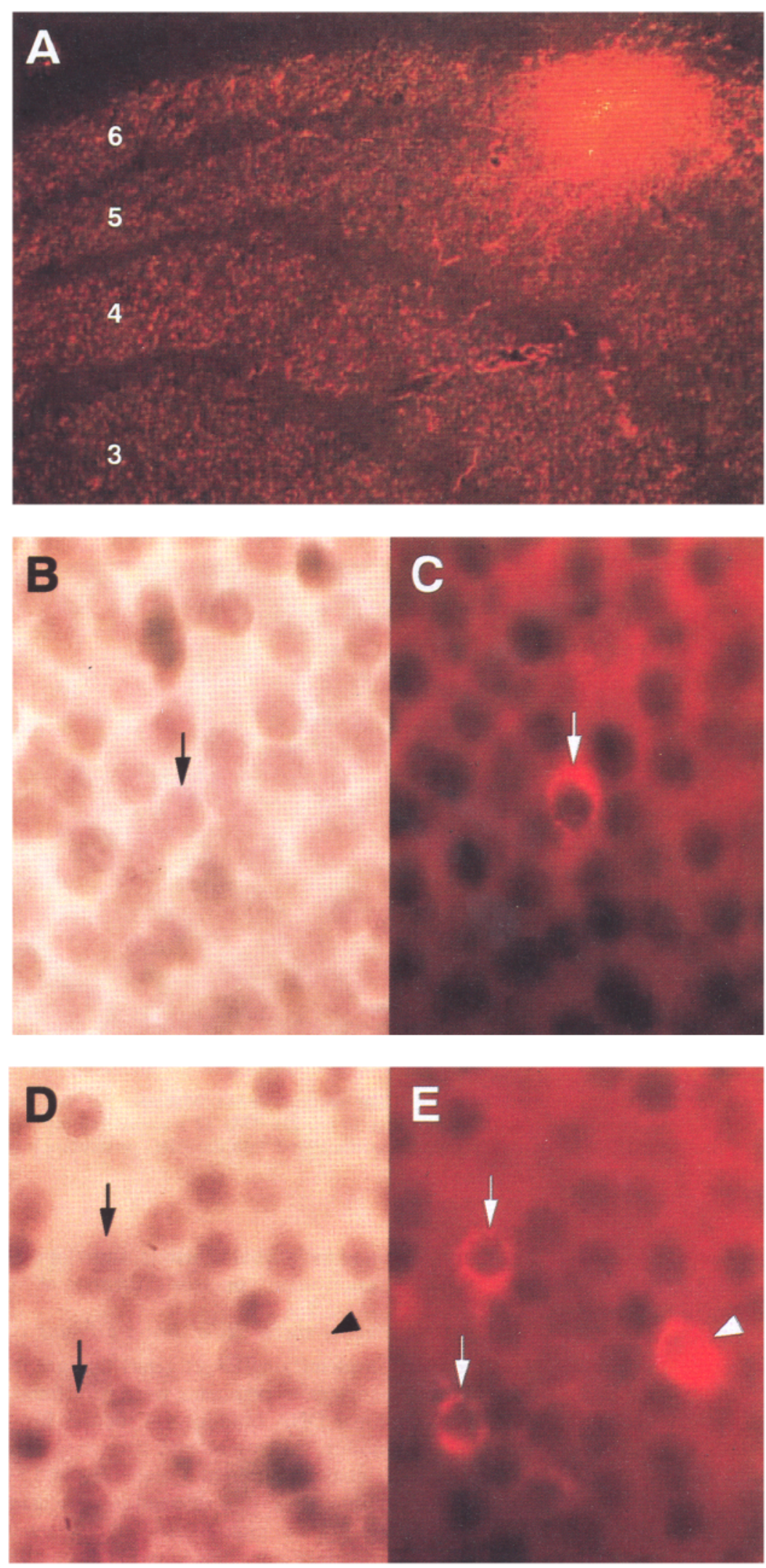

Figure 11. Immunolabeling of P-type ganglion cells by anti-Brn-3b and antiBrn-3a antibodies in the macaque retina. A, Site of injection of Texas redconjugated dextran in layer 6 of the LGN. LGN layers 3-6 are numbered. $B-E$, Backfilled retinal flat-mounts were immunostained with anti-Brn3a $(B, C)$ or anti-Brn-3b $(D, E)$. Arrows indicate backfilled cells that are strongly immunostained. The arrowhead indicates a cell that is very weakly immunostained with anti-Brn-3b antibodies. Magnification: $A, 120 \times ; B-E$, $1000 \times$ 

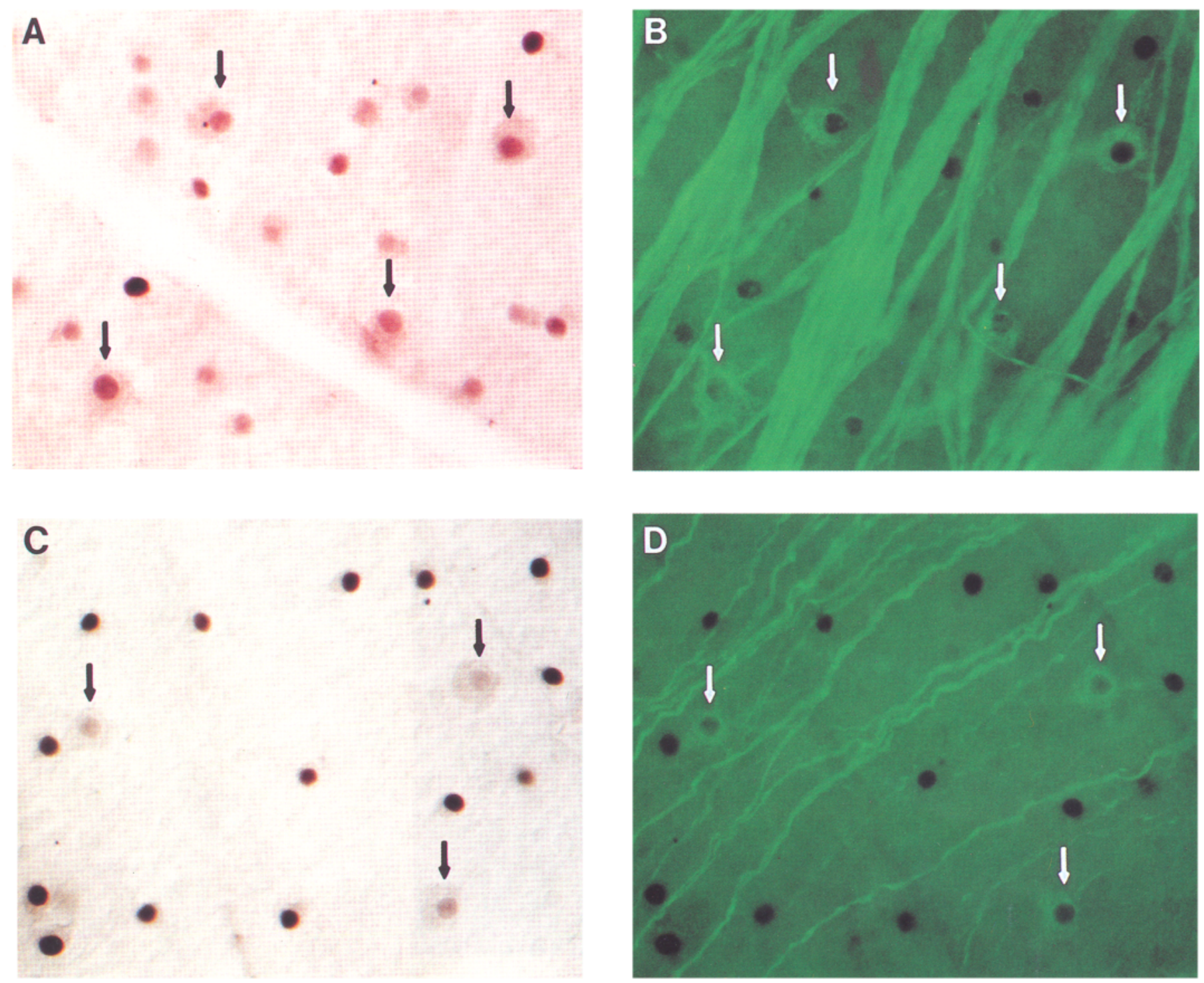

Figure 12. Colocalization of SMI-32 and anti-Brn-3a or anti-Brn-3b immunoreactivity in the macaque retina. Macaque flat-mount retinae were double immunostained with monoclonal antibody SMI-32 and anti-Brn-3a $(A, B)$ or anti-Brn-3b $(C, D)$. SMI-32 immunostaining was visualized with a fluorescein conjugated second antibody $(B, D)$; Brn-3a and Brn-3b immunostaining was visualized with the $\mathrm{ABC}$-peroxidase method $(A, C)$. Arrows point to SMI-32 labeled cells. Magnification, $400 \times$.

FP2' antibody (data not shown), the high degree of amino acid sequence homology between Brn-3a, Brn-3b, and Brn-3c in the FP1 region and the observation that the anti-Brn3a FP1 antibodies weakly cross-react with Brn-3b FP1 and Brn-3c FP1 fusion proteins suggests that they may bind to some degree to all of the Brn-3 proteins in immunohistochemical experiments. With respect to the pattern of staining observed in the retina and dorsal root and trigeminal ganglia with anti-Brn-3a FP2', we cannot rule out the possibility that some of this staining represents cross-reaction with the ubiquitous brain-specific nuclear antigen described above. However, this possibility appears unlikely in light of the observations that anti-Brn3a FP1 and anti$\mathrm{Brn} 3 \mathrm{a} \mathrm{FP} 2^{\prime}$ give similar patterns of staining in these tissues and that the cross-reacting antigen appears to be confined to the brain proper, being absent from the spinal cord, and the inner and outer nuclear layers of the retina. We note that transcripts from the mouse Brn-3a/3.0 gene have recently been localized by in situ hybridization to the medial habenula, superior colliculus, red nucleus, and inferior olivary nucleus (Turner et al., 1994).

\section{In vitro DNA binding specificity of Brn-3 proteins}

As a first step in identifying target genes that are regulated by Brn-3 family members, experiments were performed to identify in vitro the optimal DNA binding site for the Brn-3 proteins. Using a gel mobility shift assay and a starting pool of DNA oligonucleotides containing random sequences at 15 central positions, DNA binding sites were selected in vitro using the POU domain of Brn- $3 \mathrm{~b}$ fused to glutathione- $S$-transferase (GST). Following several rounds of enrichment and PCR amplification, the selected DNA segments were cloned, sequenced, and individually tested for their ability to bind the GST-Brn-3b POU domain fusion protein. Thirty-one of 33 cloned segments, representing 30 different DNA sequences, were found to bind the Brn-3b POU domain (Fig. 15A,C) and were used to derive the consen- 

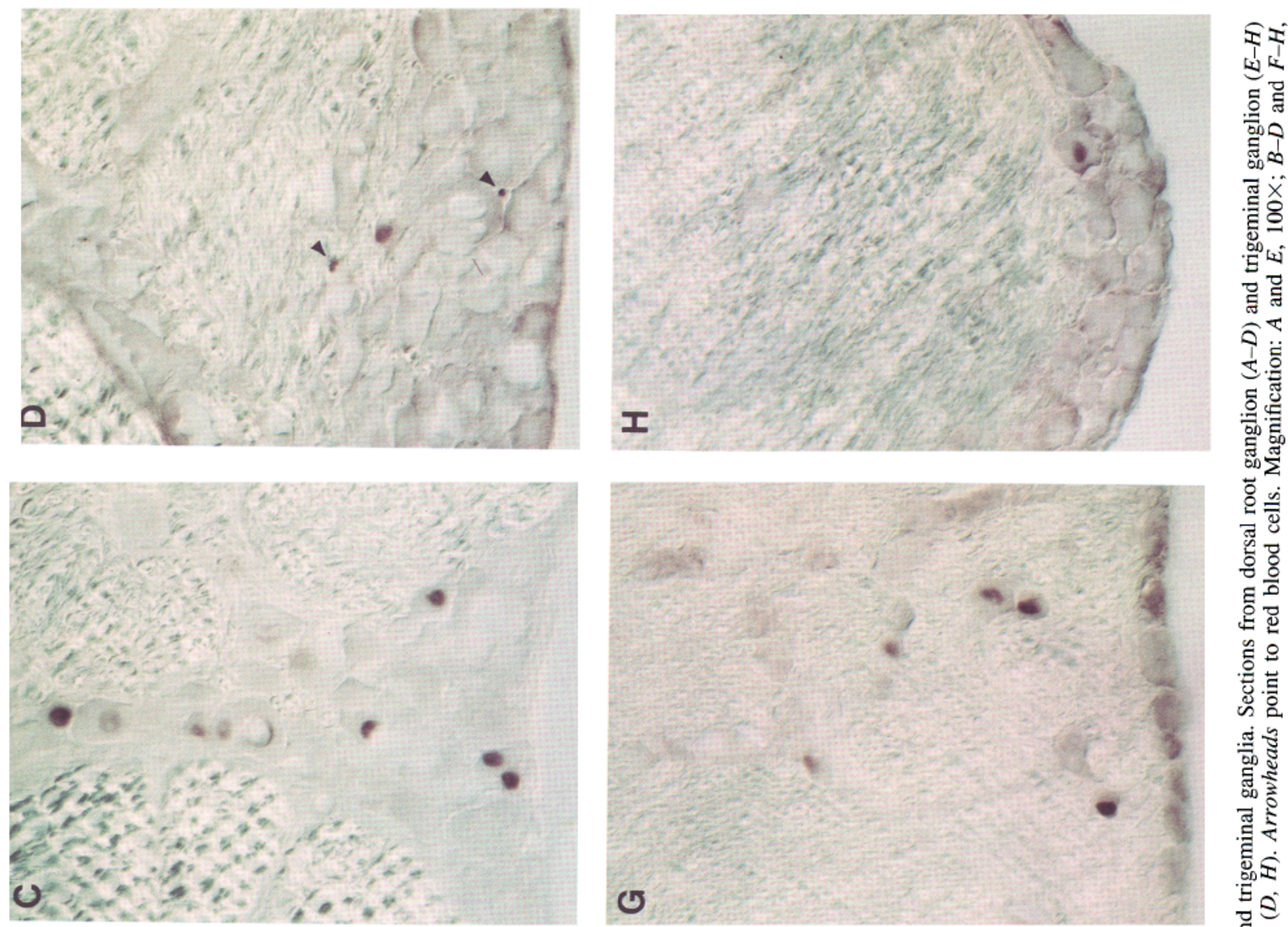

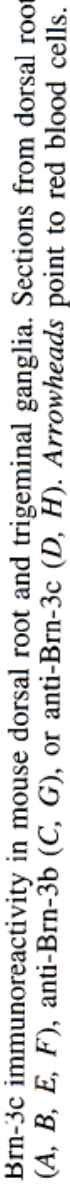
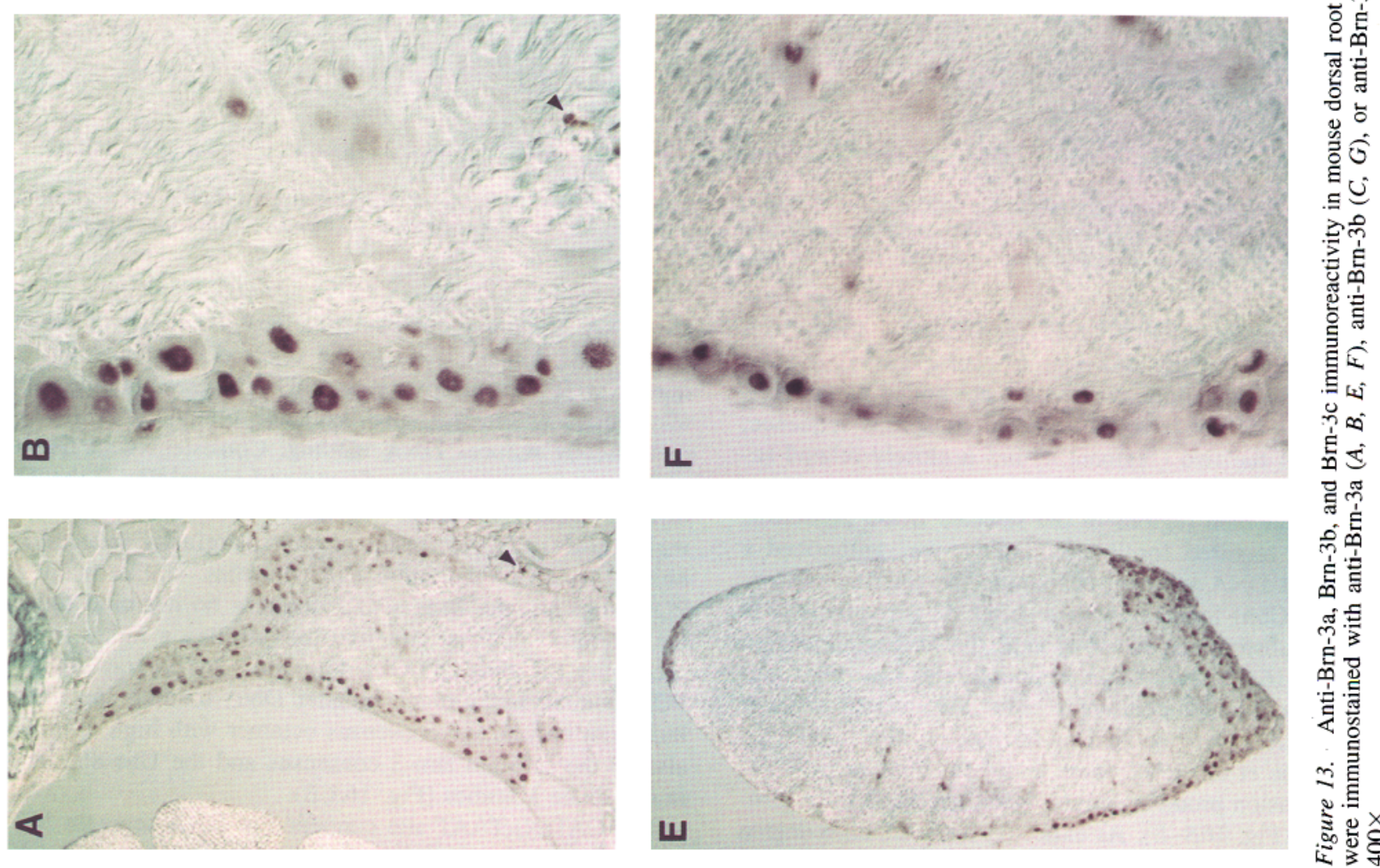

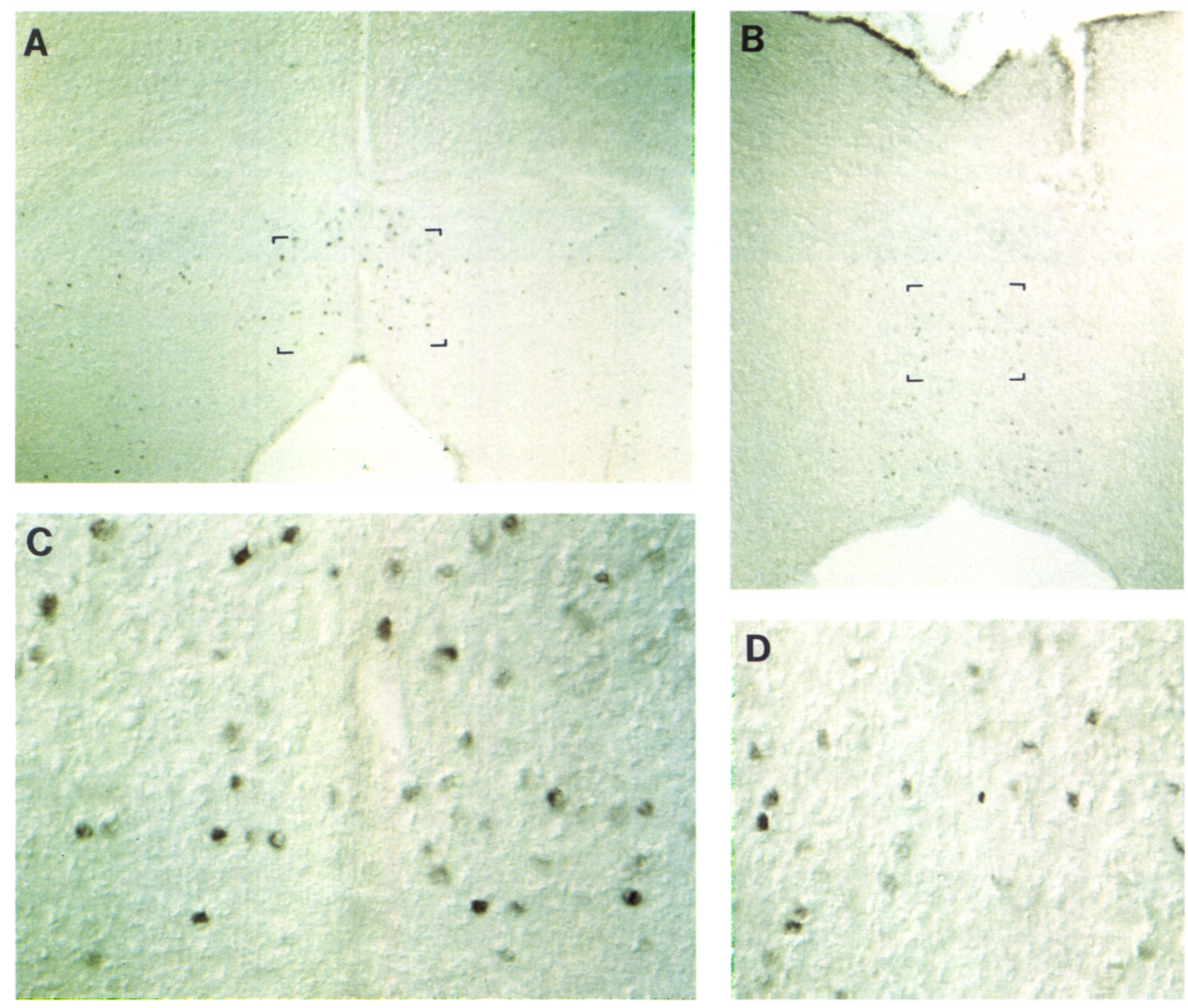

Figure 14. Anti-Brn-3c immunoreactivity in the mouse brain. $A$, The superior colliculus and adjacent periaqueductal gray. $B$, The inferior colliculus. The aqueduct is at the bottom of $A$ and $B$ and the dorsal surface of the midbrain is visible at the top of $B$. $C$ and $D$, Higher magnification views of the boxed areas in $A$ and $B$. Magnification: $A$ and $B, 100 \times ; C$ and $D, 400 \times$.

sus DNA binding site (A/G)CTCATTAA(T/C) (Fig. 15B). Each of the 31 segments contains this consensus or a close derivative of it. The two cloned segments that were not bound by the Brn3b POU domain do not have the selected consensus sequence, although one of the two (segment 4 ) has a closely related sequence (Fig. 15A).

To determine which regions of the selected Brn- 3 consensus sequence were required for Brn-3 binding, we synthesized a double stranded DNA segment containing the selected consensus sequence (Con) together with a series of derivatives containing base substitutions in or around the consensus region (M1-M6; Fig. 16A). These DNA segments, and two other segments of identical length containing either a consensus octamer site (ATGCAAAT, Oct), or an Unc-86 binding site [CAT $(\mathrm{N})_{3}$ TAAT; M7; Xue et al., 1992] were tested for binding by GSTPOU domain fusion proteins derived from Brn-3a, Brn-3b, Brn$3 c$, and Oct-1 (Fig. 16B-E). As expected from the high degree of sequence identity among the Brn-3 proteins in the POU domain (Fig. 2A), the three Brn-3 POU domains exhibit very sim- ilar DNA binding properties (Fig. 16A-D). Each of the three Brn-3 POU domains bind to the selected Brn-3 consensus sequence with high specificity, and in each case mutating pairs of nucleotides within the core sequence CTCATTAA (M2-M5) dramatically reduces DNA binding. Consistent with the loose preference for purine at the $5^{\prime}$ end and pyrimidine at the $3^{\prime}$ end of the selected sequences (Fig. 15B), mutations in the flanking regions (M1 and M6) result in only marginally reduced DNA binding by all of the Brn-3 POU domains. Unlike many other POU domains, the Brn-3 POU domains do not bind tightly to the canonical octamer site, and thus display a rather restricted specificity for their DNA binding sites. By contrast, the Oct-1 POU domain has a much broader DNA binding specificity: it binds not only to the consensus octamer with high affinity, but also to the selected Brn-3 consensus and the Unc-86 site with intermediate affinities (Fig. 16A,E).

The CAT $(\mathrm{N})_{3}$ TAAT site contained in DNA segment M7 has been shown to be a binding site in vivo and in vitro for the $C$. elegans POU-domain protein Unc-86 (Xue et al., 1992). In vitro 
A

\#

2

3

6

8

9

10

11

12

13

14

15

16

17

18

19

20

21

22

23

24

25

26

27

28

30

31

32

33

4

29

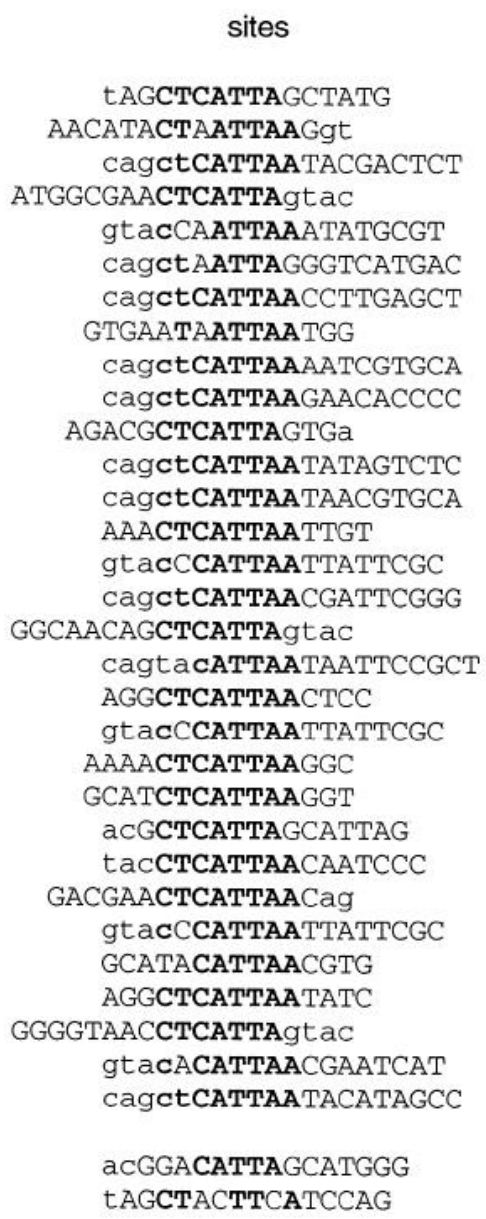

B

binding

$\begin{array}{rlrrrrrrrrrrrrrr}+ & G & 3 & 3 & 6 & 0 & 0 & 0 & 0 & 0 & 0 & 0 & 4 & 5 & 8 & 2 \\ + & \mathrm{A} & 7 & 8 & 7 & 1 & 2 & 4 & 31 & 0 & 0 & 31 & 24 & 2 & 10 & 11 \\ + & \mathrm{T} & 1 & 1 & 1 & 1 & 15 & 0 & 0 & 31 & 31 & 0 & 0 & 12 & 7 & 8 \\ + & \mathrm{C} & 2 & 2 & 1 & 14 & 4 & 26 & 0 & 0 & 0 & 0 & 0 & 9 & 1 & 4 \\ + & \text { total } & 13 & 14 & 15 & 16 & 21 & 30 & 31 & 31 & 31 & 31 & 28 & 28 & 26 & 25\end{array}$

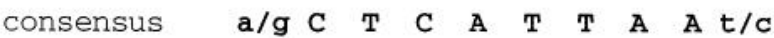

\section{C} $\begin{array}{lllllllllllllll}1 & 2 & 3 & 4 & 5 & 6 & 7 & 8 & 9 & 10 & 11 & 12 & 13 & 14 & 15\end{array}$

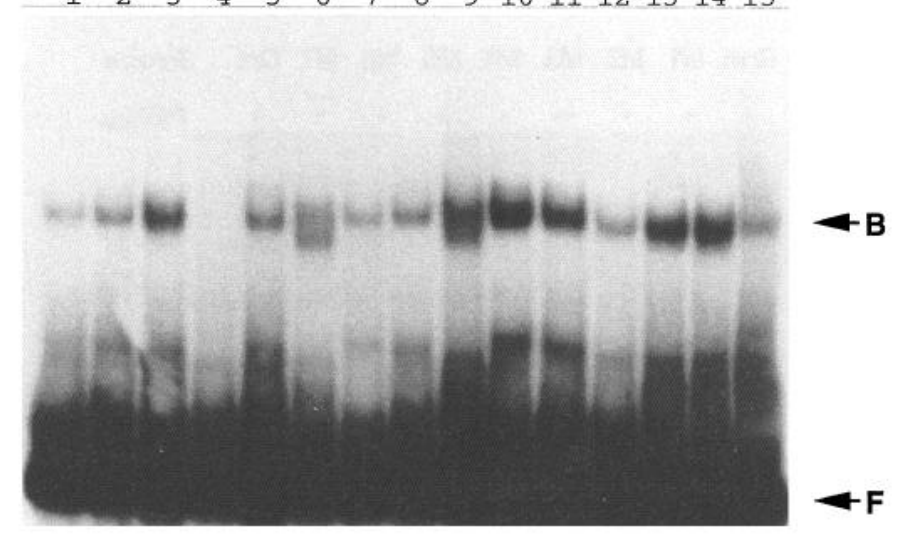

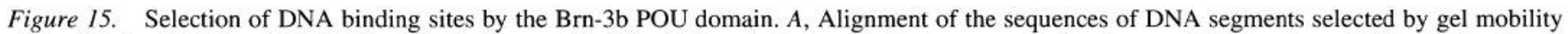

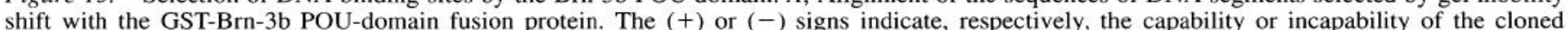

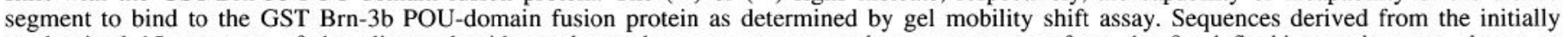

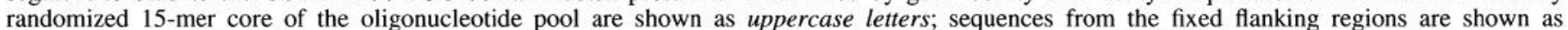

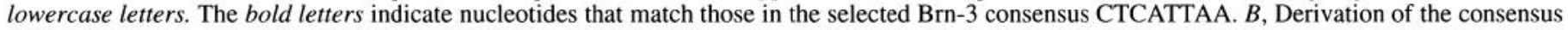

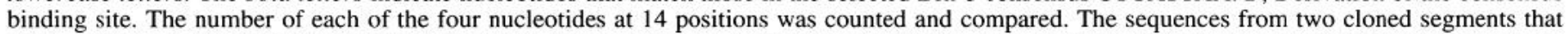

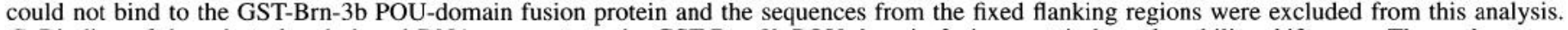

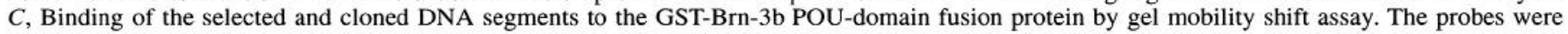
derived by PCR from each of the cloned segments ( $1-15$ shown in $A$ ). $F$, Free probe; $B$, bound probe.

binding and tissue culture transactivation experiments show that the CAT(N) $)_{3}$ TAAT sequence also binds to the murine Brn-3 proteins (Gerraro et al., 1993; Li et al., 1993; Turner et al., 1994). Surprisingly, the isolated Brn-3a and Brn-3c POU domains bind M7 poorly and the isolated Brn-3b POU domain binds with a reduced affinity relative to the selected Brn-3 consensus site (Fig. 16A-D). (In Fig. 16C the minor shifted band with higher mobility appears to result from a protein degradation product of the GST-Brn-3b POU domain fusion protein since it has a lower apparent molecular mass and the same binding properties as the intact fusion.)

To determine whether regions outside of the POU domain exert some influence on the specificity of DNA binding we investigated the DNA binding properties of full-length Brn-3b protein. Whole cell protein extracts were prepared from untransfected human embryonic kidney cells or from cells that had been transiently transfected with a Brn-3b expression construct or an Oct-2 expression construct. Full-length Brn-3b showed strong binding to the selected Brn-3 consensus site and no detectable binding to the octamer consensus (Fig. 17A). By contrast, expressed Oct- 2 and endogenous 293 S Oct- 1 bound well to the octamer consensus but poorly or not at all, respectively, to the selected Brn- 3 consensus site. A comparison of Figures 16 and 17 reveals that full-length Brn-3b resembles the isolated Brn-3b POU domain-GST fusion in its relative affinity for the selected Brn-3 consensus and its derivatives, M1-M6, but it differs from the isolated POU-domain in binding to M7 with relatively higher affinity (compare Figs. $16 C, 17 B$ ). The full-length Oct-1 (produced endogenously in $293 \mathrm{~S}$ cells) also appears to have higher DNA sequence specificity than does its isolated POU domain, as the former shows little or no detectable binding to the Brn-3 consensus site, its derivatives, or the Unc-86 consensus (Fig. 17).

To quantitate the differential affinity of full-length Brn-3 and the Brn-3 POU domain for the selected Brn- 3 consensus site and the Unc-86 binding site, we performed a competition binding experiment with a radiolabeled Brn- 3 consensus site and various ratios of unlabeled competitors (Fig. 18). With the GST-Brn-3b 
A

$\begin{array}{lc} & \text { Sites } \\ \text { Con } & \text { CACAGCTCATTAACGCGC } \\ \text { M1 } & \text { CACTCCTCATTAACGCGC } \\ \text { M2 } & \text { CACAGAGCATTAACGCGC } \\ \text { M3 } & \text { CACAGCTTGTTAACGCGC } \\ \text { M4 } & \text { CACAGCTCAGCAACGCGC } \\ \text { M5 } & \text { CACAGCTCATTGCCGCGC } \\ \text { M6 } & \text { CACAGCTCATTAAGTCGC } \\ \text { M7 } & \text { CACGCATGCGTAATGCGC } \\ \text { Oct } & \text { TTAGAAATGCAAATTACC }\end{array}$

\begin{tabular}{cccc}
\multicolumn{4}{c}{ Binding Affinity } \\
\hline Brn-3a & Brn-3b & Brn-3c & Oct-1 \\
++++ & ++++ & ++++ & ++ \\
++ & ++ & ++ & + \\
- & - & - & $+/-$ \\
- & - & - & $+/-$ \\
- & - & - & - \\
- & - & - & - \\
++ & ++ & +++ & + \\
- & + & - & + \\
- & - & - & +++
\end{tabular}

B

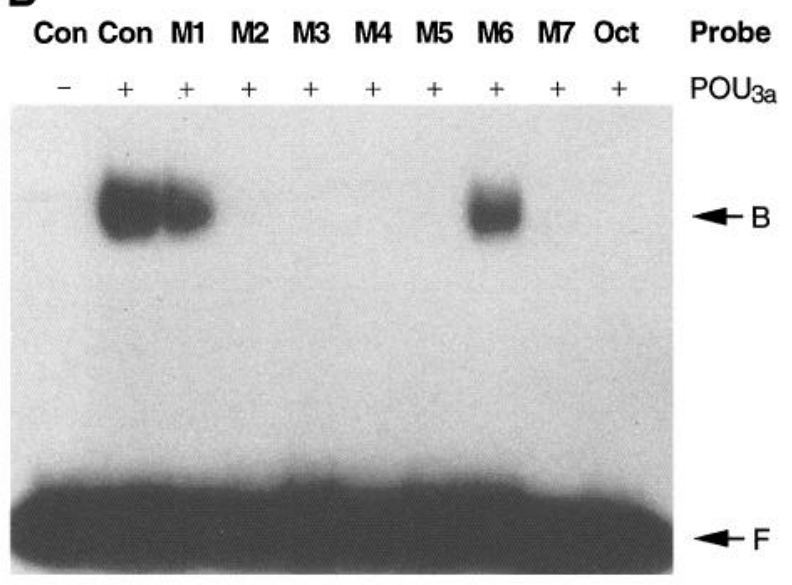

D

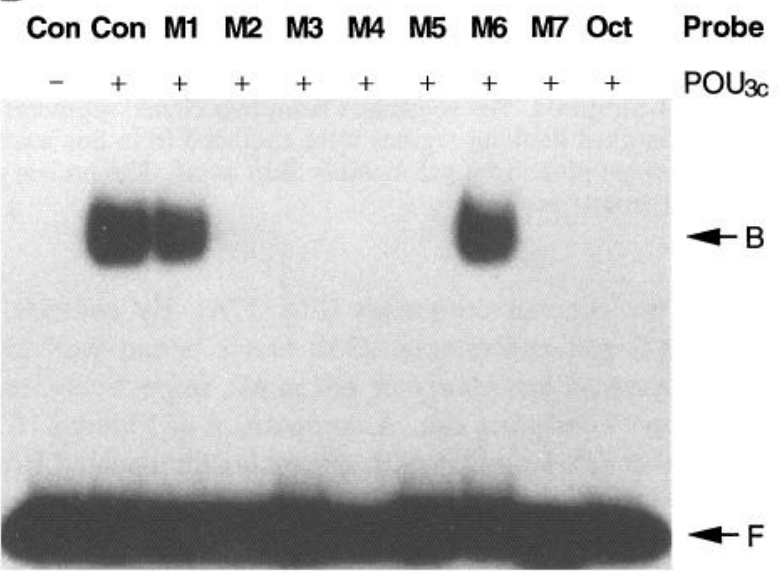

\section{C}

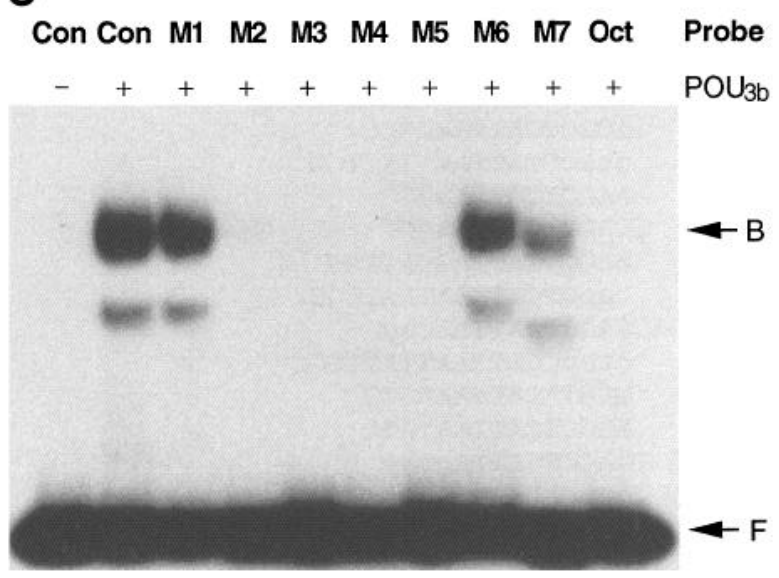

E
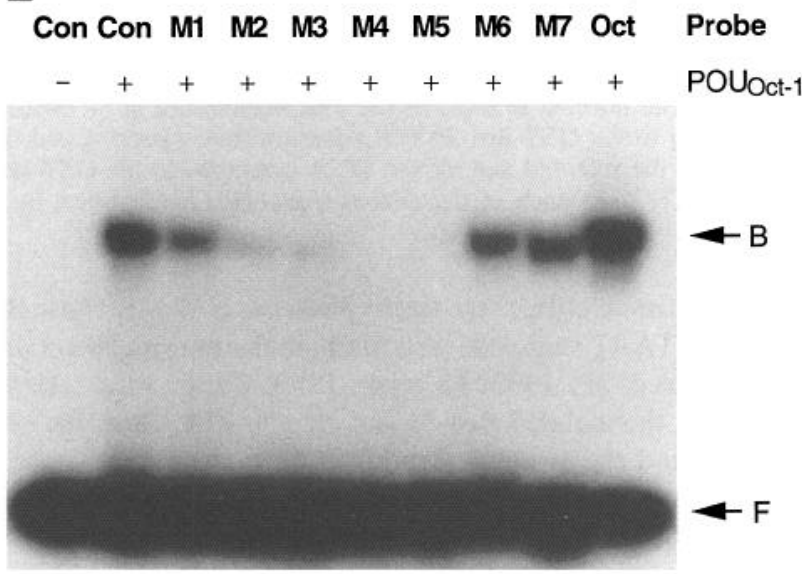

Figure 16. Gel mobility shift analysis of the binding of Brn-3 and Oct-1 GST-POU-domain fusion proteins to the selected Brn-3 consensus and to various mutant sites. A, Summary of the relative DNA binding affinity of the Brn-3 and Oct-1 POU-domains for the consensus site (Con), mutant sites (M1-6), the Unc-86 binding site (M7), and the canonical octamer site $(O c t)$. Nucleotides identical to those in the selected Brn-3 consensus CTCATTAA are shown in boldface. The CAT and TAAT motifs of M7, and the ATGCAAAT motif of the octamer site are also shown in boldface. The mutant oligonucleotide positions are underlined. The sequences shown correspond to one strand of the double-stranded DNA oligonucleotides used in the mobility shift assays. $B-E$, Gel mobility shift analysis. 5'-End labeled DNA duplexes containing the indicated sites were incubated with equal amounts of GST-Brn-3a POU-domain $(B)$, GST-Brn-3b POU-domain $(C)$, GST-Brn-3c POU-domain $(D)$, or GST-Oct-1 POU-domain $(E)$ fusion proteins, and resolved in native polyacrylamide gels. + or - , Presence or absence of the POU domain protein in the reaction mixture; $F$, free probe; $B$, bound probe. 

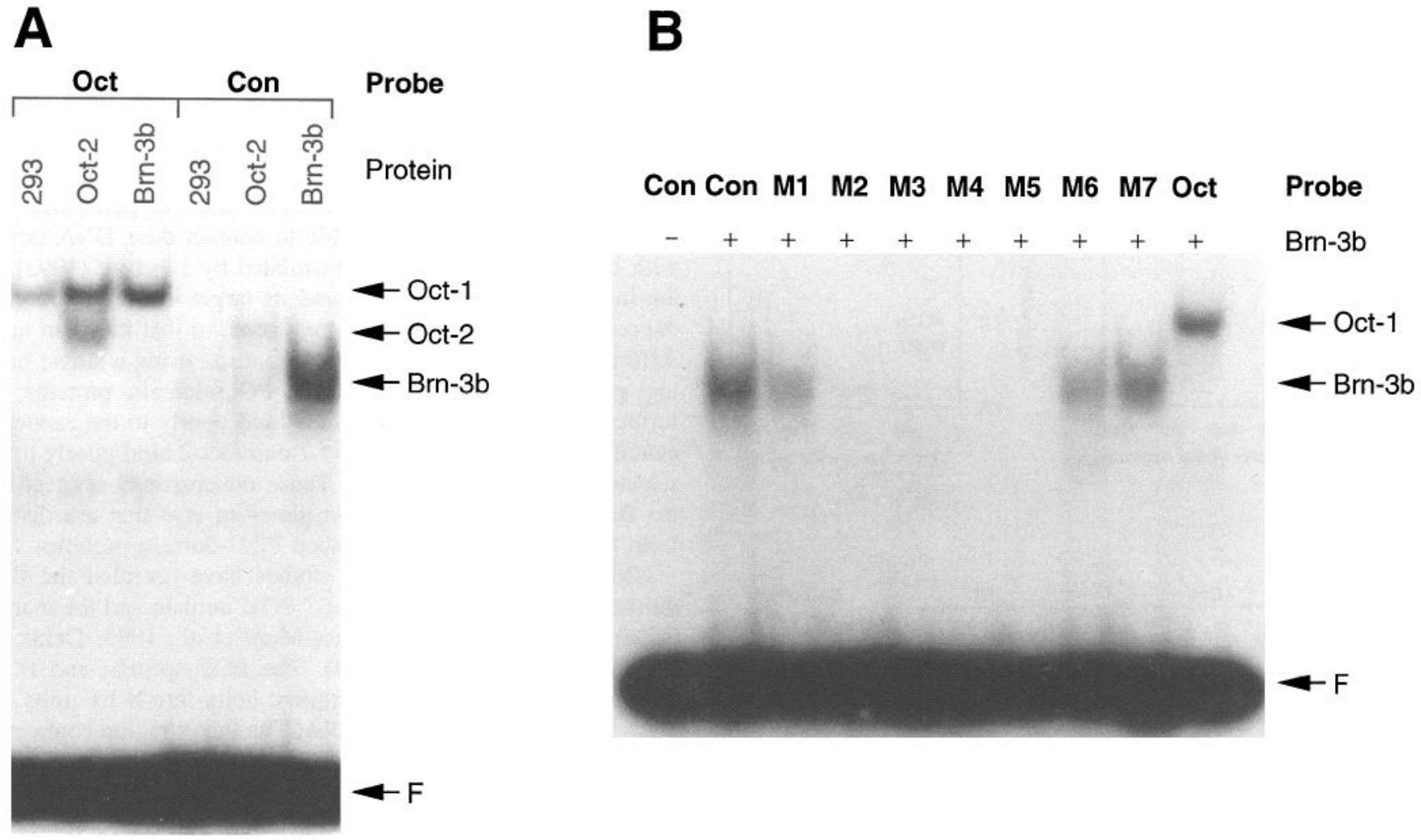

Figure 17. DNA binding specificity of full-length Brn-3b. A, Comparison of the binding of Brn-3b and Oct-2 to the selected Brn-3 consensus site (Con) and the canonical octamer site $(O c t)$. Whole cell protein extracts from 293S cells (293), and 293S cells transiently transfected with a Brn-3b expression construct $(B r n-3 b)$ or an Oct-2 expression construct $(O c t-2)$ were utilized for gel mobility shift assay. $B$, DNA binding affinity of Brn-3b for the selected Brn-3 consensus site (Con), mutant sites $(M I-6)$, the Unc- 86 binding site $(M 7)$, and the octamer site $(O c t)$. Whole cell protein extracts from $293 \mathrm{~S}$ cells transiently transfected with the Brn-3b expression construct were used for gel mobility shift assays. Mobilityshifted complexes with Brn-3b, Oct-1, and Oct- 2 are indicated by arrows. Note that all of the 293 cell extracts contain endogenous Oct-1. $F$, Free probe.

POU domain, addition of excess Brn-3 consensus competitor (Con) led to a progressive inhibition of binding with nearly complete inhibition at a 1000 -fold molar excess (Fig. 18A, left; $B$ ). An analogous binding experiment with the Unc- 86 binding site (M7) as competitor revealed a significantly lower degree of inhibition (Fig. 18A, left; $B$ ). When the competition binding experiments were carried out with full length Brn-3b, the selected Brn-3 consensus site was only marginally more effective as a competitor than the Unc-86 binding site (Fig. 18A, right; $C$ ).

In summary, these experiments demonstrate specific binding of each Brn-3 POU domain to a novel recognition site, (A/ G)CTCATTAA(T/C). Experiments with full-length Brn-3b protein expressed in mammalian cells demonstrate similar binding affinities for this site and the unrelated consensus Unc- 86 binding site, CAT(N) $)_{3}$ TAAT. Whether full-length Brn-3a and Brn-3c proteins also bind both sites with similar affinities remains to be determined.

\section{Discussion}

The Brn-3 family of POU domain genes

The experiments reported here define the human Brn-3 gene family. The three members of this family share nearly identical POU domain sequences, and in each case the POU domain is located at the extreme carboxy-terminus of the protein. Elsewhere in the protein, the amino acid sequences although still highly homologous show greater divergence. In the region ami- no-terminal to the POU domain the Brn-3a and Brn-3b proteins are distinguished by runs of simple sequences that most likely represent unstructured spacer domains. In the SCIP/Tst-1/Oct-6 POU domain protein similar runs of simple sequences are dispensable for transcriptional activation of cotransfected reporter constructs (Monuki et al. 1993). The human Brn-3 sequences reported here and in Xiang et al. (1993) are 98\% identical to their presumptive murine counterparts (Gerrero et al., 1993; Theil et al., 1993; Turner et al., 1994). That this gene family exists in similar form and performs similar functions in diverse vertebrates is suggested by the observations of strong hybridization of a human Brn-3 POU domain probe to human, mouse, and chicken genomic DNA fragments and of immunolabeling of ganglion cell subsets in mouse, cat, rabbit, monkey, and chicken retinas with each of the Brn-3-specific antibodies. In view of the direct regulation of growth hormone gene transcription by Pit-1 (Bodner et al., 1988; Ingraham et al., 1988; Li et al., 1990) and of immunoglobulin gene transcription by Oct-2 (Clerc et al., 1988; Scheidereit et al., 1988; Corcoran et al., 1993), it seems reasonable to suppose that the Brn-3 proteins are involved in genetic regulatory decisions that determine the characteristics of the ganglion cells in which they reside.

\section{Distinctive DNA binding specificity of the Brn-3 proteins}

The in vitro binding site selection experiment reported here reveals a Brn-3 consensus site (CTCATTAA) distinct from both 

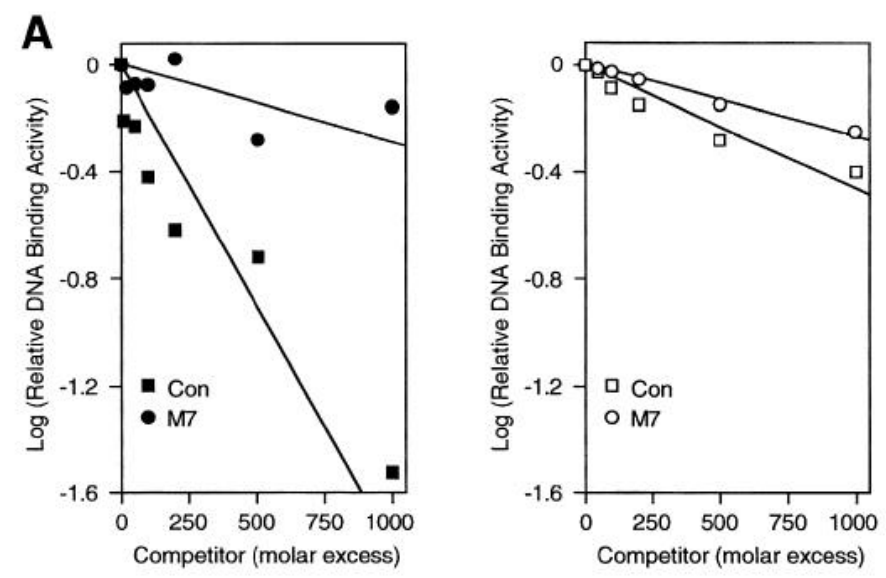

B
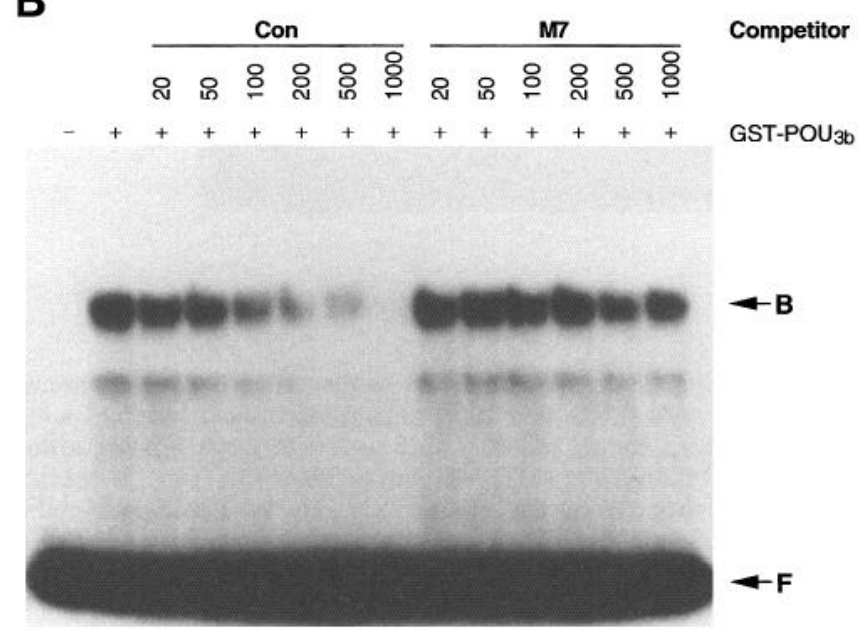

C

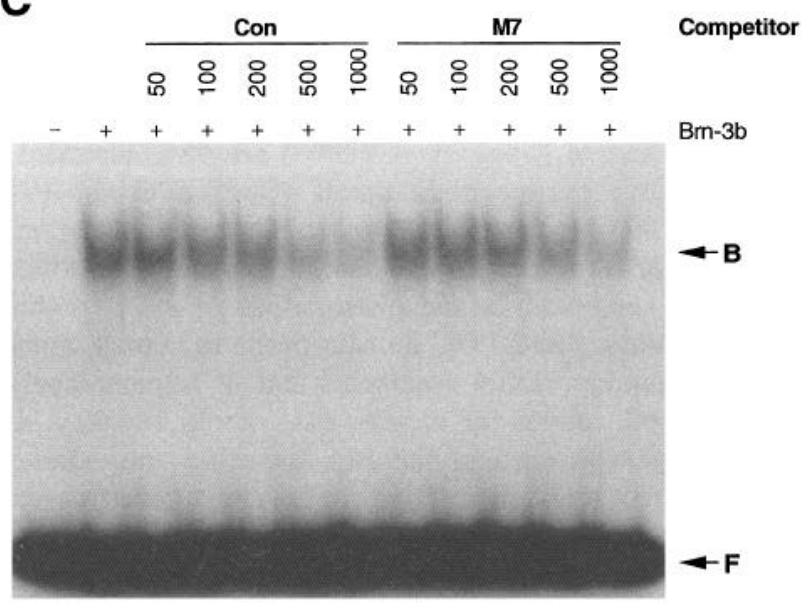

Figure 18. Competition analysis of the binding affinity of the selected Brn-3 consensus site (Con) and the Unc-86 binding site (M7) for fulllength Brn-3b and the GST-Brn-3b POU-domain fusion protein. $5^{\prime}$-End labeled duplex DNA containing the selected Brn-3 consensus site was incubated with the GST-Brn-3b POU-domain $(B)$ or with a whole-cell protein extract from $293 \mathrm{~S}$ cells transiently transfected with a Brn-3b expression construct $(C)$ in the presence of the indicated molar excess of cold Brn-3 consensus site or M7. The radioactivity present in the the canonical octamer site (TGCAAAT) and the site shown previously to bind Unc-86 and the murine Brn-3 proteins $\left(\mathrm{CAT}(\mathrm{N})_{3}\right.$ TAAT) (Xue et al., 1992; Gerraro et al., 1993; Li et al., 1993; Turner et al., 1994). In a competition experiment fulllength recombinant Brn- $3 \mathrm{~b}$ bound to the Unc- 86 binding site and to the selected Brn-3 consensus site with similar affinities. The numerous differences between the two sites suggest either that the Brn-3 POU domains are able to contact their DNA targets with different geometries, as postulated by $\mathrm{Li}$ et al. (1993) for the interaction between $\mathrm{Brn}-2$ and its target in the promotor of the corticotropin releasing hormone gene, or that they can make different but specific protein-DNA contacts using a single binding geometry. Unlike most other POU-domain proteins described thus far, the Brn-3 proteins bind poorly to the canonical octamer site, and conversely Oct- 1 and Oct- 2 bind poorly to the selected Brn- 3 consensus site. These observations suggest that the Brn-3 proteins act on target genes in vivo that are distinct from those of previously described POU-domain proteins.

NMR and x-ray diffraction studies have revealed the three dimensional structure of the Oct-1 POU domain and the manner in which it contacts DNA (Assa-Munt et al., 1993; Dekker et al., 1993; Klemm et al., 1994). The POU-specific and POUhomeo domains fold as independent helix-turn-helix units and contact opposite faces of the DNA. The linker region connecting the two DNA-binding domains is disordered in the crystal structure, and this observation, together with the protease sensitivity of the Oct-1 linker and the observed sequence divergence among linker regions from different POU domains, has led to the suggestion that the linker may be relatively flexible (Klemm et al., 1994). Alignment of the Brn-3 and Oct-1 POU-domains shows only one amino acid substitution among the seven residues involved directly in base contacts: threonine ${ }^{45}$-to-serine in the POU-specific domain (the numbering system refers to the Oct-1 POU domain; see Figs. 1 and 5 of Klemm et al., 1994). However, five amino acid substitutions occur among the 19 residues that contact phosphates. These five substitutions could conceivably affect sequence recognition either by distorting the DNA or by altering the packing of the recognition helices against the major groove of the DNA.

Alignment of the Brn-3a, Brn-3b, and Brn-3c sequences indicates that 11 of the 15 amino acid substitutions that distinguish the POU domain sequences of the three Brn-3 proteins from one another fall within the linker region. The remaining 4 substitutions involve conservative changes and when overlaid on the Oct-1 structure do not involve residues in direct contact with DNA. These sequence similarities together with the similar in vitro DNA-binding specificity of the POU domains of Brn-3a, Brn-3b, and Brn-3c predict that in the absence of specific heteromeric interactions with other factors these proteins will compete for the same DNA target sequences.

\section{Differences in Brn-3 proteins among subsets of retinal ganglion cells}

The observations described in this article, namely the identification of molecular differences between ganglion cells, introduce a new approach the classification of retinal ganglion cells. Historically, the classification of ganglion cells has been based

$\leftarrow$

mobility-shifted bands is plotted in A:Left, the GST-Brn-3b POU-domain; right, full-length Brn-3b. $F$, Free probe; $B$, bound probe. 
upon morphology, physiological response properties, and the pattern of central projections (Rodieck and Brening, 1983; Stone, 1983). Although these three approaches to classification were developed independently, they have become increasingly integrated in recent years (Wassle and Boycott, 1991). In the present work we have chosen to study proteins involved in genetic regulation with the idea that these will ultimately provide some insight into the logic of cell type differences. Because molecular differences between cell types may be conserved across species whereas cell number and some aspects of cell morphology or physiology may not, the molecular genetic approach can reveal homologies that would otherwise not be apparent. This issue is of general interest in comparative neuroscience and is of special interest in the study of ganglion cells because of the difficulties encountered in comparing potentially related cells from different species, for example, in the comparison of X-, Y-, and W-cells in the cat and P- and M-cells in the monkey (Shapley and Perry, 1986; Spillman and Werner, 1990). Cross-species comparisons are also useful in integrating human psychophysics with physiological and anatomical studies in nonhuman animals.

Immunolocalization of each of the Brn-3 proteins in a variety of mammalian retinas has revealed several broad similarities in the distribution of these proteins. First, immunoreactivity was found predominantly within nuclei, as might be expected for transcription factors. Second, in all species tested thus far-including chicken, mouse, rabbit, cat, and macaque-nearly all immunostained nuclei were found in the ganglion cell layer. The rare exceptions are located at the inner edge of the inner nuclear layer and are presumed to be the nuclei of displaced ganglion cells. Third, the staining intensity among labeled nuclei was consistently observed to be heterogeneous, with the ratio of strongly to weakly stained nuclei varying in a reproducible fashion between species. And fourth, in those cases where independent methods were used to distinguish ganglion and amacrine cellsAB5 immunolabeling of ganglion cells in rabbit and cat retinae and retrograde labeling from the $\mathrm{LGN}$ in the macaque- $\mathrm{Brn}-3$ immunoreactivity was found in the ganglion cells. Because AB5 immunolabels all ganglion cells in cat and rabbit retinae, we have been able to show in those species that each of the three Bril-3 proteins is found exclusively in ganglion cells. In the macaque, immunolabeling by anti-Brn- $3 \mathrm{a}$ and anti-Brn-3b antibodies of all or nearly all ganglion cells retrogradely filled from the LGN, together with the decline in the relative density of immunolabeled nuclei with increasing eccentricity, strongly suggests that in primates all of the Brn-3a- and Brn-3b-containing cells are also ganglion cells.

As described below, the pattern of Brn-3a, Brn3b, and Brn$3 \mathrm{c}$ immunolabeling of retinal ganglion cells in different species reveals a series of overlapping subsets of immunoreactive cells. In cat and macaque retinae, where ganglion cell types have been most thoroughly studied, we have performed a series of immunolabeling experiments aimed at identifying the ganglion cell types that express each of the Brn-3 proteins. We consider first the ganglion cells that express Brn-3a and Brn-3b. In all species tested Brn-3a and Brn-3b expressing cells were abundant. In the cat both anti-Brn-3a and anti-Brn-3b antibodies stain all or nearly all ganglion cells, although $\alpha$ and $\beta$ cells stain less strongly than $\gamma$ cells with anti-Brn-3a antibodies. The pattern of anti-Brn3 a immunostaining in the macaque retina resembles that in the cat, except that in the former only a minority of small ganglion cells stain strongly. This similarity suggests that there may be a functional correspondence between the subsets of cells in the cat and in the macaque that are strongly stained by anti-Brn-3a antibodies. The lower frequency of these cells in the macaque retina compared to their frequency in cats could be explained entirely or in part by the observation that the primate retina has approximately 10 times as many retinal ganglion cells as the cat retina due to a great expansion of the retino-geniculo-cortical pathway in general and its parvocellular division in particular (Spillman and Werner, 1990).

The pattern of Brn-3b immunostaining in the macaque provides evidence for molecular differences between $P$ and $M$ ganglion cells. In both retrograde labeling and double immunolabeling experiments with mAb SMI-32, large cells (i.e., M cells) were weakly stained and the vast majority of small cells (i.e., P cells) were strongly stained. Whether the set of small cells that stain strongly with anti-Brn-3b antibodies includes completely, partially, or not at all the set of small cells that stain strongly by anti-Brn-3a antibodies remains to be determined.

In cat and mouse retinae, the cells expressing Brn-3c are most obviously distinguished from those expressing Brn-3a or Brn$3 b$ by their relatively lower frequency. In the macaque retina the weak immunostaining with the anti-Brn-3c antibody precludes at present any definitive statement regarding the abundance and distribution of cells expressing Brn-3c. In cat and mouse retinae, the cells expressing Brn-3c were shown to constitute a subset of those expressing Brn-3a and Brn-3b, and in the cat morphometric analysis identified these as $\gamma$ cells. Unlike the $\alpha$ and $\beta$ cells, the $\gamma$ class of ganglion cells has long been known to be physiologically heterogeneous, despite their being placed within a single group in the $\mathrm{X} / \mathrm{Y} / \mathrm{W}$ classification scheme (Spillman and Werner, 1990). The $\gamma$ class has been found to include many cells that project to the superior colliculus (Wassle and Illing, 1980).

As noted above, an intriguing aspect of the Brn-3 immunolabeling patterns is the characteristic and reproducible hetcrogeneity in nuclear labeling intensity. Heterogeneity in nuclear immunostaining intensity in both mouse and macaque retinal ganglion cells has also been observed with antibodies to a fourth and highly divergent POU domain protein that we have recently identified ( $\mathrm{H}$. Zhou and J. Nathans, unpublished data), and in the inner nuclear layer, there is a gradient of immunostaining for the homeodomain protein, Chx10 (Liu et al., 1994). This heterogeneity in levels of transcription factors suggests that stable differentiated states may be determined not only by the presence or absence of different transcription factors, but by the maintenance of these factors at particular intermediate levels. A graded mechanism of this general type has been shown to mediate anterior-posterior fate determination in the Drosophila embryo, in which case concentration gradients of a small set of maternally derived regulatory proteins determine the level of expression of a larger set of target genes at different positions in the embryo (St. Johnston and Nusslein-Volhard, 1992).

\section{Shared transcription factors in visual and somatosensory neurons}

The Brn-3 genes show a pattern of expression within the adult mouse CNS that is highly restricted. Immunostaining and/or in situ hybridization localizes their expression to subsets of midbrain structures, retinal ganglion cells, subsets of cells in the dorsal root and trigeminal ganglia, and occasional cells within the dorsal spinal cord (this work; Lillycrop et al., 1992; Gerrero et al., 1993; Ninkina et al., 1993; Xiang et al., 1993; Turner et al., 1994). The prominent expression of all three Brn-3 genes in 
both the somatosensory and visual systems is intriguing in light of the fact that both systems divide a complex sensory input into parallel streams (Barlow and Mollon, 1983). The data presented here suggest an homology in the development of these two sensory systems based upon a partial overlap of transcriptional regulators.

\section{References}

Assa-Munt N, Mortshire-Smith RJ, Aurora R, Herr W, Wright PE (1993) The solution structure of the Oct-1 POU-specific domain reveals a striking similarity to the bacteriophage lambda repressor DNA-binding domain. Cell 73:193-205.

Barlow HR (1953) Summation and inhibition in the frog's retina. J Physiol (Lond) 136:469-488.

Barlow HB, Mollon JD (1983) The senses. Cambridge: Cambridge UP Bhargava AK, Li Z, Weissman SM (1993) Differential expression of four members of the POU family of proteins in activated and phorbol 12-myristate-13-acetate-treated Jurkat T cells. Proc Natl Acad Sci USA 90: 10260-10264.

Bodner M, Castrillo J-L, Theill LE, Deerinck T, Ellisman M, Karin M (1988) The pituitary-specific transcription factor $G H F-1$ is a homeobox-containing protein. Cell 55:505-518.

Boycott BB, Wassle H (1974) The morphological types of ganglion cells of the domestic cat's retina. J Physiol (Lond) 240:397-419.

Chalfie M, Horvitz HR, Sulston JE (1981) Mutations that lead to reiterations in the cell lineages of $C$. elegans. Cell 24:59-69.

Cleland BG, Levick WR, Wassle H (1975) Physiological identification of a morphological class of cat retinal ganglion cells. J Physiol (Lond) 248:151-171.

Clerc RG, Corcoran LM, Lebowitz JH, Baltimore D, Sharp PA (1988) The B-cell-specific $O_{c t-2}$ protein contains POU box- and homeo boxtype domains. Gene Dev 2:1570-1581.

Collum RG, Fisher PE, Datta M, Mellis S, Thiele C, Huebner K, Croce CM, Israel MA, Thiel T, Moroy T, DePinho R, Alt FW (1992) A novel POU homeodomain gene specifically expressed in cells of the developing mammalian nervous system. Nucleic Acids Res 20:49194925.

Corcoran LM, Karvelas M, Nossal GJV, Ye Z-S, Jacks T, Baltimore D (1993) Oct-2, although not required for early B-cell development, is critical for later maturation and for postnatal survival. Genes Dev 7:570-582.

Dacey DM (1993) The mosaic of midget ganglion cells in the human retina. J Neurosci 13:5334-5355.

Dekker N, Cox M, Boelen, R, Verrijzer CP, van der Vleit PC, Kaptein R (1993) Solution structure of the POU-specific DNA-binding domain of Oct-1. Nature 362:852-855.

DeMonasterio FM, Gouras P (1975) Functional properties of ganglion cells of the rhesus monkey retina. J Physiol (Lond) 251:167-195.

Dowling JE (1987) The retina: an approachable part of the brain. Cambridge, MA: Harvard UP.

Finney M, Ruvkin G, Horvitz HR (1988) The C, elegans cell lineage and differentiation gene unc-86 encodes a protein with a homeodomain and extended similarity to transcription factors. Cell 56:757769.

Frischauf A-M, Lehrach H, Poustka A, Murray N (1983) Lambda replacement vectors carrying polylinker sequences. J Mol Biol 170: $827-842$.

Fry KR, Lam DM-K (1986) Specific labelling of ganglion cells in the cat retina by a monoclonal antibody. Vision Res 26:373-382.

Fry KR, Tavella D, Su YYT, Peng YW, Watt CB, Lam DMK (1985) A monoclonal antibody specific for retinal ganglion cells. Brain Res 338:360-365.

Fukuda Y, Hsiao CF, Watanabe M (1985) Morphological correlates of $\mathrm{Y}, \mathrm{X}$, and $\mathrm{W}$ type ganglion cells in the cat's retina. Vision Res 25: 319-327.

Gerrero MR, McEvilly R, Turner E, Lin CR, O'Connell S, Jenne KJ, Hobbs MV, Rosenfeld MG (1993) Brn-3.0: a POU-domain protein expressed in the sensory, immune, and endocrine systems that functions on elements distinct from known octamer motifs. Proc Natl Acad Sci USA 90:10841-10845

Harlow E, Lane D (1988) Antibodies: a laboratory manual. Cold Spring Harbor, NY: Cold Spring Ilarbor Laboratory.

He X, Treacy MN, Simmons DM, Ingraham HA, Swanson LW, Rosen- feld MG (1989) Expression of a large family of POU-domain regulatory genes in mammalian brain development. Nature 340:35-42.

Herr W, Sturm RA, Clerc RG, Corcoran LM, Baltimore D, Sharp PA, Ingraham HA, Rosenfeld MG, Finney M, Ruvkin G, Horvitz HR (1988) The POU domain: a large conserved region in the mammalian Pit-1, Oct-1, Oct-2 and Caenorhabditis elegans unc-86 gene products. Genes Dev 2:1513-1516

Ingraham HA, Chen R, Mangalam HJ, Elsholtz HP, Flynn SE, Lin CR, Simmons DM, Swanson L, Rosenfeld MG (1988) A tissue-specific transcription factor containing a homcodomain specifies a pituitary phenotype. Cell 55:519-529.

Kaneko A (1970) Physiological and morphological identification of horizontal, bipolar, and amacrine cells in the goldfish retina. J Physiol (Lond) 207:623-633.

Klemm JD, Rould MA, Aurora R, Herr W, Pabo C (1994) Crystal structure of the Oct-1 POU domain bound to an octamer site: DNA recognition with tethered DNA-binding modules. Cell 77:21-32.

Lettvin J, Maturana HR, McCulloch WS. Pitts WH (1959) What the frog's eye tells the frog's brain. Proc Inst Radio Eng 47:1940-1951.

Li S, Crenshaw EB, Rawson EJ, Simmons DM, Swanson LW, Rosenfeld MG (1990) Dwarf locus mutants lacking three pituitary cell types result from mutations in the POU-domain gene Pit-1. Nature 347:528-533.

Li S, He X, Gerrero MR, Mok M, Aggarwal A, Rusenfeld MG (1993) Spacing and orientation of bipartite DNA-binding motifs as potential functional determinants for POU domain factors. Genes Dev 7:24832496.

Lillycrop KA, Budrahan VS, Lakin ND, Terrenghi G, Wood JN, Polak JM, Latchman DS (1992) A novel POU family transcription factor is closely related to Brn-3 but has a distinct expression pattern in neuronal cells. Nucleic Acids Res 20:5093-5096.

Liu ISC, Chen I, Ploder L, Vidgen D, van der Kooy D, Kalnins VI, McInnes RR (1994) Developmental expression of a novel murine homeobox gene $(\mathrm{Chx} 10)$ : evidence for roles in determination of the neuroretina and inner nuclear laycr. Ncuron 13:377-393.

Maxam A, Gilbert W (1980) Sequencing end-labeled DNA with basespecific cleavages. Methods Enzymol 65:499-560.

Merigan WH, Maunsell JHR (1993) How parallel are the primate visual pathways? Annu Rev Neurosci 16:369-402.

Monuki ES, Kuhn R, Lemke G (1993) Cell-specific action and mutable structure of a transcription factor effector domain. Proc Natl Acad Sci USA 90:9978-9982.

Nathans J. Thomas D, Hogness DS (1986) Molecular genetics of hıman color vision: the genes encoding blue, green, and red pigments. Science 232:193-202.

Naylor SL, Sakaguchi AY, Shows TB, Law ML, Goeddel DV, Gray PW (1983) Human immune interferon gene is located on chromosome 12. J Exp Med 57:1020-1027.

Ninkina NN, Stevens GEM, Wood JN, Richardson WD (1993) A novel Brn3-like POU transcription factor expressed in subsets of rat sensory and spinal cord neurons. Nucleic Acids Res 21:3175-3182.

Nixon RA, Lewis SE, Dahl D, Marotta CA, Drager UC (1989) Early post-translational modifications of the three neurofilament subunits in mouse retinal ganglion cells: neuronal sites and time course in relation to subunit polymerization and axonal transport. Mol Brain Res 5:93-108.

Paxinos G, Watson C (1986) The rat brain in stereotaxic coordinates. San Diego: Academic.

Perry VH, Cowey A (1984) Retinal ganglion cells that project to the supcrior colliculus and pretectum in the macaque monkey. Neuroscience 12:1125-1137.

Perry VH, Oehler R, Cowey A (1984) Retinal ganglion cells that project to the dorsal lateral geniculate nucleus in the macaque monkey. Neuroscience 12:1101-1123.

Rodieck RW (1973) The vertebrate retina: principles of structure and function. New York: Freeman.

Rodieck RW (1988) The primate retina. In: Comparative primate biology, Vol 4, pp 203-278. New York: Liss.

Rodieck RW, Brening RK (1983) Retinal ganglion cells: properties, types, genera, pathways, and trans-species comparisons. Brain Behav Evol 23:121-164.

Rodieck RW, Watanabe M (1993) Survey of the morphology of macaque retinal ganglion cells that project to the pretectum, superior colliculus, and parvocellular laminae of the lateral geniculate nucleus. J Comp Neurol 338:289-303. 
Rodieck RW, Binmoeller KF, Dineen J (1985) Parasol and midget ganglion cells of the human retina. J Comp Neurol 233:115-132.

Rosenfeld MG (1991) POU-domain transcription factors: pou-er-ful developmental regulators. Genes Dev 5:897-907.

Saito H-A (1983) Morphology of physiologically identified X-, Y-, and W-type retinal ganglion cells of the cat. J Comp Neurol 221:279288.

Scheidereit C, Cromlish JA, Gerster T, Kawakima K, Balmaceda C-G, Currie A, Roeder RG (1988) A human lymphoid-specific transcription factor that activates immunoglobulin genes is a homeobox protein. Nature 336:551-557.

Scholer HR, Hatzopoulos AK, Balling R, Suzuki N, Gruss P (1989) A family of octamer-specific proteins present during mouse embryogenesis: evidence for germline-specific expression of an Oct factor. EMBO J 8:2543-2550.

Shapley R, Perry VH (1986) Cat and monkey retinal ganglion cells and their visual functional roles. Trends Neurosci 9:229-235.

Shows TB, Brown JA, Haley LL, Byers MG, Eddy RL, Cooper ES, Goggin AP (1978) Assignment of the beta-glucuronidase structural gene to the pter-q22 region of chromosome 7 in man. Cytogenet Cell Genet 21:99-104.

Shows TB, Sakaguchi AY, Naylor SL (1982) Mapping of the human genome, cloned genes, DNA polymorphisms, and inherited disease. In: Advances in human genetics, Vol 12 (Harris H, Hirschorn K, eds), pp 341-452. New York: Plenum.

Shows TB, Eddy RL, Haley L, Byers M, Henry M, Fujita T, Matsui $\mathbf{H}$, Taniguchi $\mathrm{T}$ (1984) Interleukin 2 (IL2) is assigned to human chromosome 4. Somat Cell Mol Gen 10:315-318.

Sidman RL, Angevine JB, Pierce TP (1971) Atlas of the mouse brain and spinal cord. Cambridge, MA: Harvard UP.

Silveira LCL, Perry VH (1991) The topography of magnocellular projecting ganglion cells (M-ganglion cells) in the primate retina. Neuroscience 40:217-237.

Smith DB, Corcoran LM ( 1991) Expression and purification of glutathione- $S$-transferase fusion proteins. In: Current protocols in molecular biology (Ausubel FM, Brent R, Kingston RE, Moore DD, Seidman JG, Smith JA, Struhl K, eds), pp 16.7.1-16.7.8. New York: Greene/Wiley-Interscience.

Spillman L, Werner JS (1990) Visual perception: the neurophysiological foundations. New York: Academic.

St Johnston D, Nusslein-Volhard C (1992) The origin of pattern and polarity in the Drosophila embryo. Cell 68:201-218.

Stone J (1983) Parallel processing in the visual system: the classifi- cation of retinal ganglion cells and its impact on the neurobiology of vision. New York: Plenum.

Studier FW, Rosenberg AH, Dunn JJ, Dubendorff JW (1990) Use of T7 RNA polymerase to direct expression of cloned genes. Methods Enzymol 185:60-89.

Tanaka M, Herr W (1990) Differential transcriptional activation by Oct- 1 and Oct-2: interdependent activation domains induce Oct-2 phosphorylation. Cell 60:375-386.

Theil T, McLean-Hunter S, Zornig M, Moroy T (1993) Mouse BRN-3 family of POU transcription factors: a new aminoterminal domain is crucial for the oncogenic activity of BRN-3A. Nucleic Acids Res 21: $5921-5929$.

Thiesen H-J, Bach C (1990) Target detection assay (TDA): a versatile procedure to determine DNA binding sites as demonstrated on Spl protein. Nucleic Acids Res 18:3203-3209.

Treacy M, He X, Rosenfeld MG (1991) I-POU: a POU domain protein that inhibits neuron-specific gene activation. Nature 350:577-584.

Treacy MN, Neilson LI, Turner EE, He X, Rosenfeld MG (1992) Twin of I-POU: a two amino acid difference distinguishes an activator from an inhibitor of transcription. Cell 68:491-505.

Turner EE, Jenne KJ, Rosenfeld MG (1994) Brn-3.2: a Brn-3-related transcription factor with distinctive central nervous system expression and regulation by retinoic acid. Neuron 12:205-218.

Vinson CR, LaMarco KL, Johnson PF, Landschulz WH, McKnight SL (1988) In situ detection of sequence-specific DNA binding activity specificd by a recombinant bactcriophagc. Genes Dev 2:801-806.

Wassle H, Boycott BB (1991) Functional architecture of the mammalian retina. Physiol Rev 71:447-479.

Wassle H, Illing RB (1980) The retinal projection to the superior colliculus in the cat: a quantitative study with HRP. J Comp Neurol 190: 333-356.

Wassle H, Grunert U, Rohrenbeck J, Boycott BB (1989) Cortical magnification factor and the ganglion cell density in the primate retina. Nature 341:643-646.

Watanabe M, Rodieck RW (1989) Parasol and midget ganglion cells of the primate retina. J Comp Neurol 289:434-454.

Werblin FS, Dowling JE (1969) Organization of the retina of the mudpuppy, Necturus maculosus. II. Intracellular recording. J Neurophysiol 32:339-355.

Xiang M, Zhou L, Peng Y-W, Eddy RL, Shows TB, Nathans J (1993) Brn-3b: a POU domain gene expressed in a subset of retinal ganglion cells. Neuron 11:689-701.

Xue D, Finney M, Ruvkun G, Chalfie M (1992) Regulation of the mec-3 gene by $C$. elegans homeoproteins UNC- 86 and MEC-3. EMBO J 11:4969-4979. 